\title{
The Vascular Effects of Isolated Isoflavones-A Focus on the Determinants of Blood Pressure Regulation
}

\author{
Henrique Silva ${ }^{1,2}$ (D) \\ 1 Informetrics Research Group, Ton Duc Thang University, Ho Chi Minh City 758307, Vietnam; \\ henriquesilva@tdtu.edu.vn \\ 2 Faculty of Pharmacy, Ton Duc Thang University, Ho Chi Minh City 758307, Vietnam
}

Citation: Silva, H. The Vascular Effects of Isolated Isoflavones-A Focus on the Determinants of Blood Pressure Regulation. Biology 2021, 10, 49. https://doi.org/10.3390/biology 10010049

Received: 23 November 2020 Accepted: 2 January 2021 Published: 12 January 2021

Publisher's Note: MDPI stays neutral with regard to jurisdictional clai$\mathrm{ms}$ in published maps and institutional affiliations.

Copyright: () 2021 by the author. Licensee MDPI, Basel, Switzerland. This article is an open access article distributed under the terms and conditions of the Creative Commons Attribution (CC BY) license (https:// creativecommons.org/licenses/by/ $4.0 /)$.
Simple Summary: Isoflavones are naturally-occurring phytoestrogens, highly prevalent in soybeans, and known to improve cardiovascular health in populations with a high isoflavone dietary intake. Most clinical studies have assessed the impact of dietary intake or supplementation with mixtures of isoflavones, with few studies dedicated to the effects of isolated compounds (i.e., genistein, daidzein, glycitein, formononetin, biochanin $\mathrm{A}$, and equol). This paper reviews the main actions of isolated isoflavones on the vasculature, with particular focus on the determinants of blood pressure regulation. Isoflavones evoke relaxation of different vascular beds by acting on several signaling pathways in the endothelium, where they potentiate the release of important vasorelaxant mediators, and in vascular smooth muscle cells, where relaxation is attained mainly through hyperpolarization. Some of these effects are attributed to their ability to modulate estrogen receptors. These vascular effects occur at plasma concentrations in the micromolar range, attained only through dietary supplementation. This paper highlights isolated isoflavones as potentially suitable alternatives to soy-based foodstuffs and supplements and which could enlarge the current therapeutic arsenal.

Abstract: Isoflavones are phytoestrogen compounds with important biological activities, including improvement of cardiovascular health. This activity is most evident in populations with a high isoflavone dietary intake, essentially from soybean-based products. The major isoflavones known to display the most important cardiovascular effects are genistein, daidzein, glycitein, formononetin, and biochanin A, although the closely related metabolite equol is also relevant. Most clinical studies have been focused on the impact of dietary intake or supplementation with mixtures of compounds, with only a few addressing the effect of isolated compounds. This paper reviews the main actions of isolated isoflavones on the vasculature, with particular focus given to their effect on the determinants of blood pressure regulation. Isoflavones exert vasorelaxation due to a multitude of pathways in different vascular beds. They can act in the endothelium to potentiate the release of NO and endothelium-derived hyperpolarization factors. In the vascular smooth muscle, isoflavones modulate calcium and potassium channels, leading to hyperpolarization and relaxation. Some of these effects are influenced by the binding of isoflavones to estrogen receptors and to the inhibition of specific kinase enzymes. The vasorelaxation effects of isoflavones are mostly obtained with plasma concentrations in the micromolar range, which are only attained through supplementation. This paper highlights isolated isoflavones as potentially suitable alternatives to soy-based foodstuffs and supplements and which could enlarge the current therapeutic arsenal. Nonetheless, more studies are needed to better establish their safety profile and elect the most useful applications.

Keywords: isoflavones; vasorelaxation; endothelium; ion channels; estrogen receptor; tyrosine kinase

\section{Introduction}

Phytoestrogens are naturally occurring plant phenolic compounds resembling the molecular structure of estrogens, in particular 17- $\beta$-estradiol. They can exert both estrogenic and/or anti-estrogenic effects by acting on the estrogen receptors, changing the 
levels of sex-hormone-binding globulin (SHBG) and changing the estrogen plasma concentration and excretion [1,2]. In plants, phytoestrogens do not function as hormones, but rather as phytoalexins-inducible secondary metabolites that accumulate during stress and microbe attacks [3]. These compounds exert antimicrobial (i.e., fungistatic, antibacterial, and antiviral) and antioxidant properties, besides preventing the development of plant tumors due to their anti-angiogenic activity [4]. Phytoestrogens can be subdivided into two groups: flavonoids, which include isoflavones, coumestans, and prenylflavonoids; and non-flavonoids, which comprise lignans [5]. Isoflavones are considered to be very potent phytoestrogens, even though they display several other biological actions, including protective effects on the metabolism [6] and in the musculoskeletal [7] and cardiovascular systems [8], and having anticancer properties [9].

Isoflavones decrease overall cardiovascular risk by exerting important anti-hypertensive and anti-atherosclerotic effects in vitro and in vivo, the latter both in animal models as well as in clinical studies [10]. Most human studies conducted thus far have mainly investigated the effects of isoflavone-rich diets [11,12], plant extracts [13], and mixtures of isoflavones [14], with only a few studies having focused on the effect of isolated isoflavones.

The primary dietary source of isoflavones are legumes of the Fabaceae family [15], namely, soybeans (Glycine max), soy-based products (i.e., miso, tempeh, and tofu), lupin (Lupinus spp.), fava beans (Vicia faba), kudzu (Pueraria lobata), psoralea (Psoralea spp.), and red clover (Trifolium pratense) $[5,16,17]$. In these sources, particularly in soybeans and soy-based products, the predominant isoflavones with beneficial properties for the cardiovascular system are genistein, daidzein, and glycitein [18,19], and through regular dietary intake they reach physiologically relevant levels in the bloodstream [20-23]. Other isoflavones currently recognized as beneficial for cardiovascular health are formononetin and biochanin A, present in red clover [17], soybeans [24,25], peanuts (Arachis hypogaea) [26], chickpeas (Cicer arietinum) [27], Indian rosewood (Dalbergia sissoo) [28], golden tree (Cassia fistula) [29], and alfalfa sprouts (Medicago sativa) [30], as well as in Huangqi (Astragalus membranaceus) [31], a herb used in traditional Chinese medicine [17]. The concentration of formononetin and biochanin A is sufficiently low in these sources to prevent reaching physiologically relevant levels through dietary intake. As such, these isoflavones are employed in studies mainly as extracts or as isolated compounds [13,32-34]. Some of these compounds are metabolized by mammals to equol, an isoflavan that is not naturally occurring and therefore not considered a phytoestrogen, despite also possessing important biological effects [35]. In plants, isoflavones are typically present in their glycosylated form, which includes $\beta$-glycosides (i.e., genistin, daidzin, glycitin, puerarin, ononin, sissotrin, etc.), malonyl glycosides, and acetyl glycosides. The glycoside forms of isoflavones are considered biologically inactive in animals, gaining activity only after they are hydrolyzed and their corresponding aglycone forms are released and made available for absorption [36].

The beneficial effects of isoflavones for cardiovascular health have become increasingly apparent in recent decades due to the popularity of soy-based foodstuffs in Western diets. In fact, soybeans have been raised to the rank of a functional food since the discovery of their biological potency [37]. So far, it has been demonstrated that isoflavones display important vasorelaxant [38], anti-angiogenic [39], antioxidant [40], and cholesterol-lowering [41] properties, which justify their potency.

Epidemiological studies suggest the existence of an inverse relationship between the high consumption of soybeans and of red clover isoflavones and cardiovascular risk $[12,42,43]$. In particular, several studies have shown that Asian females, whose consumption of soybeans and derived products is considered high, show a low frequency of post-menopausal symptoms (i.e., hot flushes) [44]. For this reason, isoflavones are currently being studied as estrogen-mimetics for hormone replacement therapy [45].

Several meta-analyses of the epidemiological and clinical trials conducted in Asian and Western populations published thus far have shown that the dietary intake of soy isoflavones lowers blood pressure sufficiently in hypertensive and pre-hypertensive subjects [46-50] to the point that they can lower overall cardiovascular risk [51]. Table 1 
summarizes the main findings of the most recently published systematic reviews and meta-analyses on the anti-hypertensive effects of dietary intake of isoflavones.

Table 1. Description and main results of the clinical studies on the blood pressure-lowering effects of isoflavones (SBP systolic blood pressure, DBP - diastolic blood pressure).

\begin{tabular}{|c|c|c|c|}
\hline Authors & $\begin{array}{c}\text { Study Type } \\
\text { (Number of Studies Considered) }\end{array}$ & Isoflavone-Containing Product & Main Results \\
\hline Hooper et al. (2008) [46] & $\begin{array}{l}\text { Systematic review and meta-analysis } \\
\text { of randomized clinical trials }(n=83)\end{array}$ & $\begin{array}{l}\text { Soybeans, soy protein isolate, and } \\
\text { isoflavone extracts }\end{array}$ & Significant decrease in DBP \\
\hline Arenas et al. (2008) [47] & $\begin{array}{l}\text { Systematic review and meta-analysis } \\
\text { of observation studies and clinical } \\
\text { trials }(n=14)\end{array}$ & Soy products & $\begin{array}{l}\text { No significant variations in SBP or } \\
\text { DBP between subjects treated with } \\
\text { isoflavones and non-treated subjects }\end{array}$ \\
\hline Taku et al. (2010) [48] & $\begin{array}{l}\text { Systematic review and meta-analysis } \\
\text { of randomized clinical trials }(n=14)\end{array}$ & Isoflavones extract & $\begin{array}{l}\text { Significant decrease in SBP in } \\
\text { normotensive and in } \\
\text { pre-hypertensive patients, with } \\
\text { greater effects in interventions } \\
\text { longer than } 3 \text { months }\end{array}$ \\
\hline Dong et al. (2011) [49] & $\begin{array}{l}\text { Systematic review and meta-analysis } \\
\text { of randomized clinical trials }(n=27)\end{array}$ & Soy protein containing isoflavones & $\begin{array}{l}\text { Significant decrease in SBP and DBP } \\
\text { in normotensive and in } \\
\text { hypertensive subjects, more } \\
\text { markedly in the latter. Blood } \\
\text { pressure reductions were related to } \\
\text { the pre-treatment BP levels of the } \\
\text { subjects and the type of control diet } \\
\text { used as comparison }\end{array}$ \\
\hline Liu et al. (2011) [50] & $\begin{array}{l}\text { Systematic review and meta-analysis } \\
\text { of randomized clinical trials }(n=11)\end{array}$ & Soy protein containing isoflavones & $\begin{array}{l}\text { Significant decrease in SBP and DBP } \\
\text { in hypertensive subjects ( } n=5 \text { trials) } \\
\text { but not in normotensive subjects } \\
(n=6 \text { trials })\end{array}$ \\
\hline Yan et al. (2017) [51] & $\begin{array}{l}\text { Systematic review and meta-analysis } \\
\text { of observational studies }(n=17)\end{array}$ & Soy products & $\begin{array}{l}\text { Significant negative correlation } \\
\text { between soy intake and the risk of } \\
\text { cardiovascular disease, stroke, and } \\
\text { coronary heart disease }\end{array}$ \\
\hline Namazi et al. (2018) [52] & $\begin{array}{l}\text { Systematic review and meta-analysis } \\
\text { of cohort studies }(n=7)\end{array}$ & Soy products & $\begin{array}{l}\text { No significant association between } \\
\text { high consumption of soy products } \\
\text { and lower risk of mortality from } \\
\text { cardiovascular disease }\end{array}$ \\
\hline Nachvak et al. (2019) [53] & $\begin{array}{l}\text { Systematic review and meta-analysis } \\
\text { of prospective studies }(n=24)\end{array}$ & Soybeans and soy products & $\begin{array}{c}\text { Inverse relationship between } \\
\text { consumption of soy products and } \\
\text { cardiovascular mortality }\end{array}$ \\
\hline Li et al. (2020) [54] & $\begin{array}{l}\text { Umbrella review of epidemiological } \\
\text { and clinical studies }(n=114)\end{array}$ & Soybeans and soy products & $\begin{array}{c}\text { Generally, isoflavone consumption } \\
\text { is more beneficial than detrimental. } \\
\text { A beneficial role in cardiovascular } \\
\text { disease was observed }\end{array}$ \\
\hline
\end{tabular}

Nonetheless, these epidemiological and clinical studies are limited by several factors, including (A) the chemical heterogeneity of the assessed foodstuffs/extracts/mixtures; and (B) the metabolism of isoflavones, which may itself depend on the age and gender of the subjects. The chemical composition of isoflavone-containing foodstuffs is known to depend on the botanical origin itself, but also on the food preparation process, as it was shown that isoflavone glycosides remain unmodified during several food preparation procedures $[55,56]$. For example, most soy-based foodstuffs have low levels of aglycones compared to glycosides, whereas fermented products show a higher aglycone content [57]. In addition, it is presently unclear whether isoflavones are handled similarly when consumed from different foodstuffs. It is thought that the interindividual differences in the proportion of intestinal bacteria may be responsible for a considerable fraction of such variability $[58,59]$.

These factors increase the variability of the response, which hinders the understanding of what bioactive compounds may be responsible for the observed beneficial effects. There- 
fore, it becomes critical to assess the effect of the administration of isolated isoflavones on the cardiovascular system. This paper aims to review the main actions of isoflavones on the blood pressure-regulation mechanisms with particular focus given to the currently known mechanisms underlying their vasorelaxant effect. Several reviews, both comprehensive and systematic, have been published on the cardiovascular effects of isoflavones, including their vasorelaxant effects. However, to the author's knowledge, the present review provides the most thorough mechanistic description of isoflavone-mediated vasorelaxation; it also covers more cellular pathways and includes more isoflavones than the previously published reviews. By providing such a thorough description of the currently known vascular mechanisms, as well as including several aspects on pharmacodynamics and pharmacokinetics, this review aims to establish a rationale for drug design as well as to improve the conception of future experimental studies.

\section{Chemical Characterization, Metabolism, and Safety}

In general, isoflavone glycosides are not bioavailable and, thus, not biologically active. After ingestion, they are hydrolyzed into aglycones by the $\beta$-glucosidase enzymes present in the intestinal mucosa and in microbial flora, rendering isoflavones bioavailable $[35,60]$. Aglycones are then either absorbed or undergo further metabolism by intestinal flora or mucosa or by the liver before being excreted. The metabolic pathways for the majority of these isoflavones are well known in rats but less in humans. For all isoflavones, intestinal flora plays such an important role in their bioavailability that their effect has been shown to be highly dampened by an antibiotic treatment course [61]. The molecular structure of the isoflavones and biologically active metabolites discussed in this paper is shown in Figure 1.
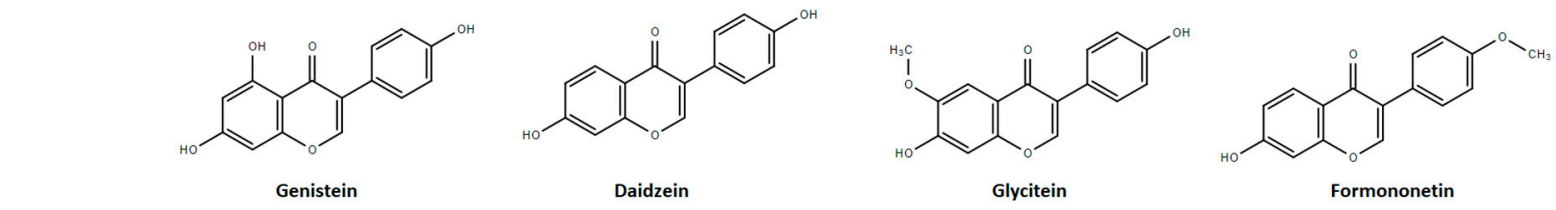

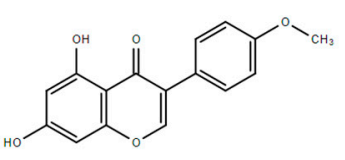

Biochanin A

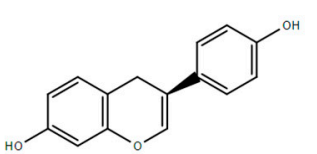

S(-)-Equol

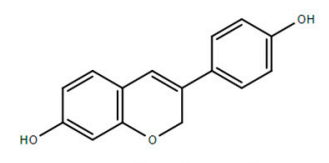

Dehydroequol

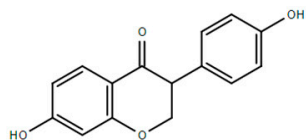

Dihydrodaidzein

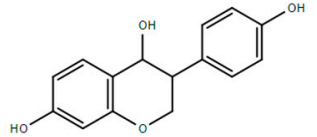

Tetrahydrodaidzein

Figure 1. Molecular structure of the five main isoflavones in their aglycone form (genistein, daidzein, glycitein, formononetin, biochanin A) and of the metabolites $\mathrm{S}(-)$-equol, dehydroequol, dihydrodaidzein, and tetrahydrodaidzein.

Genistein (7,4'-dihydroxy-6-methoxyisoflavone), also known as genisteol or prunetol, has a molecular mass of $270.24 \mathrm{~g} / \mathrm{mol}$, an octanol-water partition coefficient $(\log \mathrm{P})$ of 3.04 [62] and low solubility in water $(5.3 \mu \mathrm{M})$, the latter being responsible for its low bioavailability [63,64]. Ginestein is the aglycone form of genistin [65]. Genistein is absorbed in the gastrointestinal tract mainly by passive diffusion in a region-dependent manner, with higher absorption rates being found in the duodenum and colon and lower rates in the jejunum and terminal ileum [66]. Absorption may be limited by the breast cancer resistance protein $(\mathrm{BCRP})[67,68]$, with the differential expression of this transporter in the gastrointestinal mucosa accounting, at least in part, for the observed heterogeneity in terms of absorption. For example, BCRP has a lower expression in the colon, which justifies the high absorption rate in that region [69]. The intestinal mucosa and the liver both contribute to the first-pass effect, metabolizing genistein to genistein-glucuronide and genisteinsulfate [70]. Genistein is finally excreted in the urine and feces as dihydrogenistein, 6'$\mathrm{OH}$-O-desmethylangolensin, trihydroxybenzene, and 3', 4',5,7-tetrahydroxyisoflavone, as well as unmodified $[70,71]$. There are inconsistent results regarding its oral bioavailability in rats. It has been reported that genistein shows higher bioavailability than genistin in young non-anesthetized rats [65], which is in accordance to a previous study conducted in 
caco-2 cells [72]. Another study, however, reported a higher bioavailability for genistein in rats of similar age and weight [64]. Nonetheless, oral administration of genistin shows comparable plasma levels compared to genistein administration alone, indicating rapid and complete intestinal hydrolysis, with no effect on absorption [69]. Gender is a factor that affects genistein absorption in rats, with females showing considerably higher rates than males [70,73]. In clinical studies, genistein shows moderate absorption after oral administration of soy supplements rich in genistein or genistin [74,75].

Daidzein (7,4'-dihydroxyisoflavone), also known as daidzeol, is a lipophilic compound with a molecular mass of $254.24 \mathrm{~g} / \mathrm{mol}$ and a $\log \mathrm{P}$ of 2.51 [62]. Daidzein is the aglycone form of both daidzin and puerarin [76]. In plants, daidzein is conjugated mainly with glucose, but also with 6"-O-malonyl or 6"-O-acetylglucose [77,78]. Daidzein is almost completely metabolized by the intestinal mucosa, intestinal flora, and by the liver [79]. In the intestine, bacteria metabolize daidzein to desmethylangolensin, dihydrodaidzein, and cis-4-OHequol by demethylation and reduction processes [80]. Following this biotransformation, daidzein is converted in the liver into more hydrophilic products, such as glucuronide, sulfate, and sulfoglucuronide conjugates, which may affect its biological activity [81]. Daidzein is excreted unmodified in the urine [71] as well as in the form of other metabolites. The bioavailability of daidzein has been reported to be lower than that of genistein [82]. In the bloodstream, $80 \%$ of daidzein is transported bound to SHBG [83].

Glycitein (7,4'-dihydroxy-6-methoxyisoflavone) has a molecular mass of $284.26 \mathrm{~g} / \mathrm{mol}$, with a $\log \mathrm{P}$ of 1.97 [62]. Glycitein undergoes little metabolism, mostly by intestinal bacteria that reduce it to dihydroglycitein, $2^{\prime}, 4^{\prime}, 4^{\prime \prime}$-Trihydroxy- $5^{\prime}$-methoxy- $\alpha$-methyldeoxybenzoin (5'-OMe-O-dma), and 6-OMe-equol [71]. Glycitein is stable, because the immediate proximity of the 6-methoxyl and the 7-hydroxyl groups blocks the demethylation process. Therefore, glycitein is not converted to daidzein and does not generate equol [5].

Formononetin (7-hydroxy-4'-methoxyisoflavone) is a lipophilic compound with a molecular mass of $268.26 \mathrm{~g} / \mathrm{mol}$ and a $\log P$ of 2.58 [84]. Due to its lipophilic character, it is absorbed via passive diffusion in the intestine, especially in the small intestine, showing a peak absorption at $30 \mathrm{~min}$ [85]. During first pass metabolism, formononetin is rapidly O-demethylated into daidzein before undergoing conjugation to glucuronides and/or sulfates [86]. Therefore, formononetin can also generate equol. In rats, formononetin was determined to have a half-life of $\sim 2-3 \mathrm{~h}$ after oral administration and $\sim 2 \mathrm{~h}$ after intravenous administration $[85,87]$.

Biochanin A (5,7-dihydroxy-4'-methoxyisoflavone) has a molecular mass of $284.26 \mathrm{~g} / \mathrm{mol}$, and is deemed poorly water soluble $(7 \mathrm{mg} / \mathrm{mL})$ with no mention of a calculated $\log P$ in the literature [88]. Its poor oral bioavailability seems to be attributed to stomach degradation, susceptibility to hydrophilic degradation in the gastrointestinal tract, and extensive hepatic first-pass metabolism [86]. In rats, the metabolism of biochanin A is well known. In the intestine, bacteria demethylate biochanin A into genistein, which can then be metabolized in the liver to glucuronic and sulfonic conjugates, as well as undergo several hydroxylation reactions [37,89]. Biochanin A itself can undergo glucuronidation and sulfation, as well as hydroxylation. Finally, the hydroxylated products of biochanin A can themselves be demethylated into the hydroxylated products of genistein [89].

Equol (4',7-dihydroxyisoflavan) is not an isoflavone but rather an isoflavan. It is a lipophilic metabolite of daidzein, with a molecular weight of $242.27 \mathrm{~g} / \mathrm{mol}$ and a $\log \mathrm{P}$ of 3.20 [62]. As a result of the chiral center at the C-3 carbon position, equol exists in two enantiomeric forms, $R$-(+)-equol and $S-(-)$-equol, with the latter being the natural diastereoisomer produced by intestinal bacteria in humans and rats [90]. In the bloodstream, $50 \%$ of equol is transported bound to SHBG [91]. Although not formally a phytoestrogen, it shares some structural features with estradiol, with its estrogenic properties having been suspected back in the 1940s, where the infertility observed in ewes grazing subterranean clover pastures in Australia, the so called "clover disease", was attributed mainly to formononetin and biochanin A, with the former being converted into equol [92,93]. Although the majority of animals produce equol, only $20-50 \%$ human adults are capa- 
ble of producing it in high amounts, as was observed in several studies following a soy challenge $[35,80,94]$. Thus, individuals have been classified as "equol producers" if their equol plasma concentration reaches values above $20 \mathrm{mg} / \mathrm{L}$ and as "equol non-producers" if their concentrations are lower than $10 \mathrm{mg} / \mathrm{L}$ [35]. The prevalence of equol producers varies according to geographical distribution, with an estimated $30-50 \%$ in Western populations and up to $60 \%$ in vegetarians or Asians [95], with high prevalence confirmed to depend on a high dietary intake [96]. These differences may depend on interindividual variability in terms of the composition of the intestinal flora as well on the composition of the diet itself [80]. Interestingly, it has been shown that short-term supplementation with isoflavones can stimulate the flora to produce equol and convert "equol non-producers" into "equol producers" [97]. Some authors have proposed that soy consumption only lowers cardiovascular risk in subjects that produce equol [35], whereas others have suggested that the cardiovascular benefit in equol-producers is not significant [98]. Still, it is known that the intestinal conversion of daidzein to equol is not necessary to exert its vasorelaxant activity in all vascular beds [99]. However, equol appears to have a slightly higher vascular antioxidant activity and a longer plasma half-life than daidzein in humans [100], which probably renders it more interesting as a therapeutic drug. Whole soy foods (less processed soy products, such as soy milk, soy nuts, soy flour, tofu, etc.) are more effective than isolated soy components and a purified single isoflavone is more effective than complex isoflavones [98].

Although generally perceived as safe, a considerable number of studies have highlighted several health risks associated with the intake of isoflavones, which must be taken into account. Prenatal and postnatal exposure to high levels of isoflavones has been associated with abnormalities in the reproductive organs in both genders, which may be irreversible and affect sexual function in adults [101-103]. Moreover, this exposure has been associated with an increased risk of uterine cancer [104] and with the probable risk of infant leukemias [105]. Prenatal exposure to isoflavones is possible since these compounds cross the placental barrier and access the fetal circulation [106]. Postnatal exposure is primarily due to consumption of soy-based infant formulae, soy milk, and soy food supplements [20,107], and not due to breast milk, which, irrespective of the dietary habits of the mother, excretes low levels of isoflavones [108]. Besides exposure, the apparent bioavailability of isoflavones in children is known to be higher than in adults, which contributes to these effects [109].

Several epidemiological studies have been published on the relation between the intake of soy-based products and the risk of dementia, with conflicting results. Although some studies have linked tofu and tempeh consumption to dementia in the elderly, the authors have attributed the presence of formaldehyde in one of the products to the increased risk of dementia, not isoflavones themselves [110]. Besides this, these studies also showed methodological limitations that preclude more consistent conclusions [111,112]. Several posterior clinical trials have shown more optimistic results but is still affected by a lack of internal consistency [113].

It has been established in vitro and in vivo that isoflavones, mainly genistein, can inhibit thyroid peroxidase, an enzyme involved in the biosynthesis of thyroid hormones [114]. In addition, genistein and, to a lower extent, daidzein compete with thyroxin in the attachment to transthyretin in vitro [115], the main transport protein for thyroid hormones. These effects might suppose that isoflavones change thyroid hormone homeostasis. However, given that an adequate iodine intake is present, there is no risk of thyroid disease, as found in children [116], healthy adults, pre- and post-menopausal women [117], and in hypothyroidism patients [118]. Still, studies describing the effects of isoflavones on subclinical hypothyroid patients and in iodine-deprived patients are lacking.

Several in vitro and preclinical studies have shown that isoflavones, mainly genistein, daidzein, and biochanin A, display interesting anti-cancer properties against several neoplasms, including prostate, pancreas, lung, skin, breast, and colon, among others [119]. Meta-analyses have indeed confirmed the protecting role of dietary isoflavones 
for prostate [120] and colorectal [121] cancers. However, there are conflicting results regarding other neoplasms, namely, breast and bladder cancers. Regarding bladder cancer, dietary intake of isoflavones has been both positively [122,123] and negatively correlated [124] with risk. Intake dose seems to be an important determinant of the histological progression and, therefore, of the prognosis of the disease [125]. Several studies have shown that dietary intake of isoflavones is associated with a lower risk of breast cancer [126-128]. In Asian countries, where the isoflavone intake is higher than in Western countries, the prevalence of breast cancer is lower $[129,130]$. It is also suggested that isoflavone intake during childhood or maturing may lower the risk of breast cancer in later years [131]. However, there are studies showing that consumption of soy foods has no protective effects against breast cancer [132]. Also, it appears that isoflavones may stimulate epithelial cell proliferation in the breasts of premenopausal women [133]. Regarding uterine cancer, the current results are inconclusive. Even though a high intake of anti-estrogenic isoflavones might constitute protection against cervical cancer [134]. One study reported lower isoflavone intake in a group of uterine cancer patients [135] while another found that a 6-month intake did not prevent cervical hyperplasia induced by exogenous estradiol [136]. Finally, in grazing animals, such as sheep and horses, the ingestion of large amounts of clover, rich in formononetin and biochanin A, causes "clover disease", characterized by sexual dysfunction $[92,137,138]$.

\section{Vasorelaxant Effects of Isoflavones In Vitro}

Vascular tone is defined as the basal degree of constriction sustained by each blood vessel when not subjected to any kind of stimuli. The increase in vascular tone (i.e., vasoconstriction) leads to an increase in vascular resistance, which leads to a downstream decrease in tissue perfusion and to an upstream increase in blood pressure. When vascular tone decreases (i.e., vasodilation), vascular resistance decreases, which leads to an increase in tissue perfusion and to a decrease in blood pressure $[139,140]$. Several mediators, neural, endocrine and local, contribute to the regulation of vascular tone. Neural mediators include neurotransmitters released by afferent nerve fibers, such as substance P and calcitonin gene-related peptide, as well as by the post-ganglionic sympathetic and parasympathetic nerve fibers, such as norepinephrine (NE)/epinephrine and acetylcholine (Ach), respectively. Endocrine mediators with important vasoactive effects include epinephrine/NE, angiotensin II, endothelin-1, vasopressin, insulin, among several others. Local mediators include endothelial substances, such as nitric oxide (NO); endothelium-derived hyperpolarization factors (EDHFs); autacoids, such as thromboxane $\mathrm{A}_{2}\left(\mathrm{TXA}_{2}\right)$; and mediators released by immune cells, including histamine, bradykinin, and substance P. Most of these mediators can exert either vasoconstriction or vasodilation, depending on the type of vessel and on the receptors they bind to $[139,141]$, and change the vascular tone and caliber by acting either in the endothelium or in the vascular smooth muscle (VSM).

Several mediators, including NE/epinephrine, serotonin (5-HT), angiotensin II, vasopressin, and TXA $\mathrm{T}_{2}$, act directly on the receptors localized on the VSM cell membrane which, via $G$ proteins, open the receptor-operated calcium channels (ROCC). The entry of calcium from the extracellular fluid drives the release of more calcium from the endoplasmic reticulum. The resulting cytosolic calcium causes contraction by binding to calmodulin, which leads to the activation of myosin light chain kinase (MLCK), which changes the myofibrils spatial organization. Moreover, calcium influx directly causes VSM cell depolarization, which opens L-type-voltage-gated calcium channel (VGCC), further strengthening contraction [142]. Relaxation of the VSM cell occurs with the removal of calcium from the cytosol and with the activation of the myosin light chain phosphatase (MLCP), an enzyme that opposes the effects of MLCK on myofibrils. The activity of MLCP can be suppressed by the RhoA-associated kinase (ROCK) enzyme, favoring VSM contraction [143].

The endothelium constitutively expresses the endothelial isoform of nitric oxide synthase (eNOS), an enzyme that produces the powerful vasorelaxant NO. Due to its low molecular weight and to its lipophilic character, NO rapidly diffuses to VSM cells 
and activates the enzyme guanylyl cyclase, which, in turn, raises the intracellular cyclic guanosine monophosphate (cGMP) and leads to a change in myofibrils spatial organization, causing cell relaxation [144]. The levels and activity of eNOS can be affected by extracellular mediators (e.g., 17- $\beta$-estradiol) [145], by several intracellular mediators (e.g., calmodulin and caveolin-1) and pathways (e.g., PI3K/PTEN/Akt and MAPK) [144]. The endothelium also synthesizes mediators that cause hyperpolarization of the endothelial cells and/or of the VSM cells, probably by opening the potassium and/or chloride channels. The resulting potassium efflux and/or chloride influx cause hyperpolarization, which prevents the opening of VGCCs and of calcium influx. It is currently thought that those mediators, collectively termed EDHFs, include hydrogen peroxide, prostanoids, epoxyeicosatrienoic and eicosatrienoic acids (EETs and ETs, respectively) [146].

The vasorelaxant effects of a given test substance can be assessed by incubating it with a blood vessel ring in the presence of known substances that will either contract or relax that vessel via specific cellular pathways. Depending on whether it will potentiate or suppress the effects of other substances, the vascular mechanism of the test substance can then be inferred.

The vasorelaxant effects of isoflavones are attributed to multiple pathways, both in endothelial and in VSM cells and are described in Figure 2. There is a multitude of proposed mechanisms for genistein-induced vasorelaxation as this compound induces vasorelaxation in several vascular beds, including in rat aortae, carotid and pulmonary arteries preconstricted by several inducers, including phenylephrine (PE), potassium chloride (KCl), 5-HT, fluoride, phorbol ester, and TXA 2 (Table 2) [79,147-153]. The proposed mechanisms for genistein-mediated vasorelaxation are shown in Figure 2a. Daidzein is known to relax several vascular beds, including the aortic, mesenteric and basilar arteries by both endothelium-dependent and endothelium-independent mechanisms, which do not seem to be site-specific (Table 3). The proposed mechanisms for daidzein-mediated vasorelaxation are shown in Figure 2b. Formononetin is known to relax several vascular beds, including the aorta, mesenteric, renal, coronary, and cerebral arteries [154]; however, most studies have been performed in the first two, where the relaxation response is more potent, having led to a deeper comprehension of endothelium-dependent and -independent mechanisms (Table 4). The proposed mechanisms for formononetin-mediated vasorelaxation are shown in Figure 2c. Two studies have reported that biochanin A is the most potent vasorelaxant of the major phytoestrogen isoflavones $[38,155]$. It induces vasorelaxation by acting both in the endothelium and in VSM cells. Most studies have been conducted in the aortae of healthy and diseased animals. In healthy animals, results suggest that biochanin A-mediated vasodilation is endothelium-independent, whereas in diseased animals it seems to depend on the pathophysiology of the disease itself (Table 5). The proposed mechanisms for biochanin A-mediated vasorelaxation are shown in Figure $2 \mathrm{~d}$. Few studies on the vasorelaxation evoked by glycitein or by the metabolites equol, deydroequol, dihydrodaidzein and tetrahydrodaidzein are available (Table 6). Current knowledge suggests that these compounds act in the endothelium and in VSM cells, and their proposed mechanisms of vasorelaxation are shown in Figure 2e. 


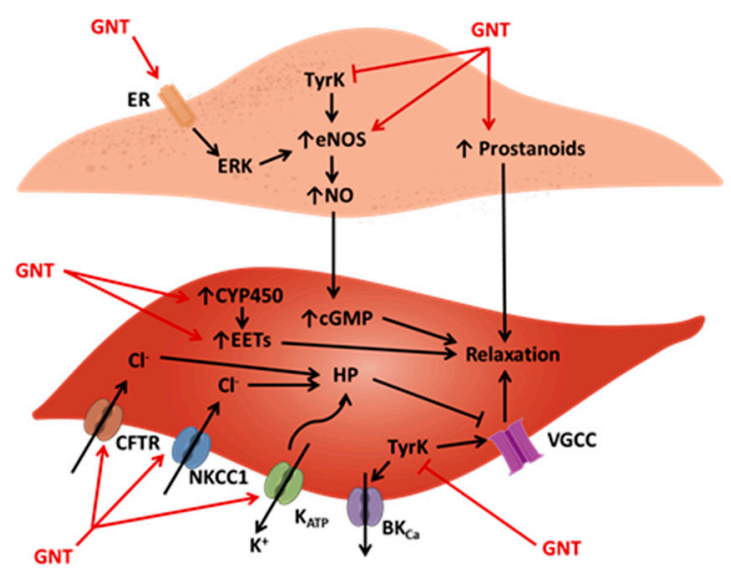

(a)

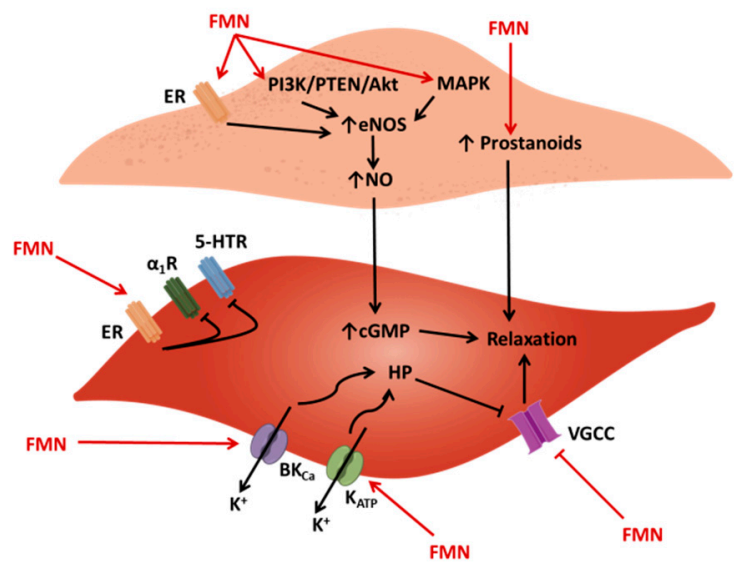

(c)

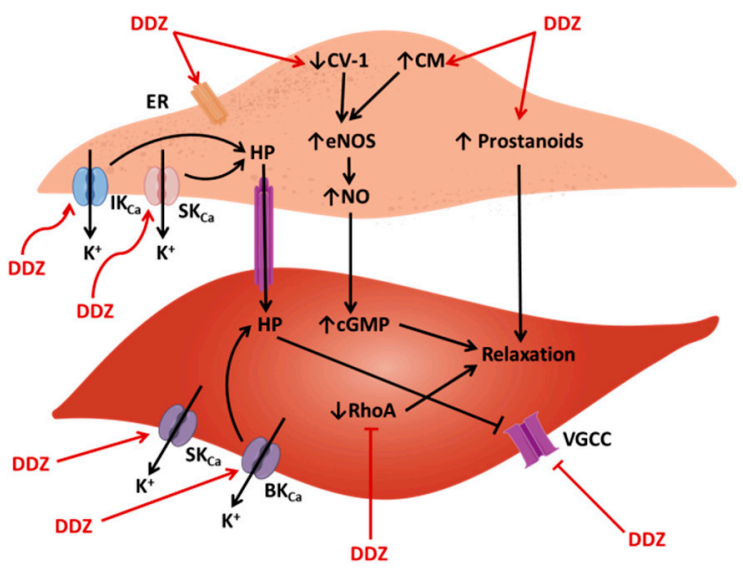

(b)

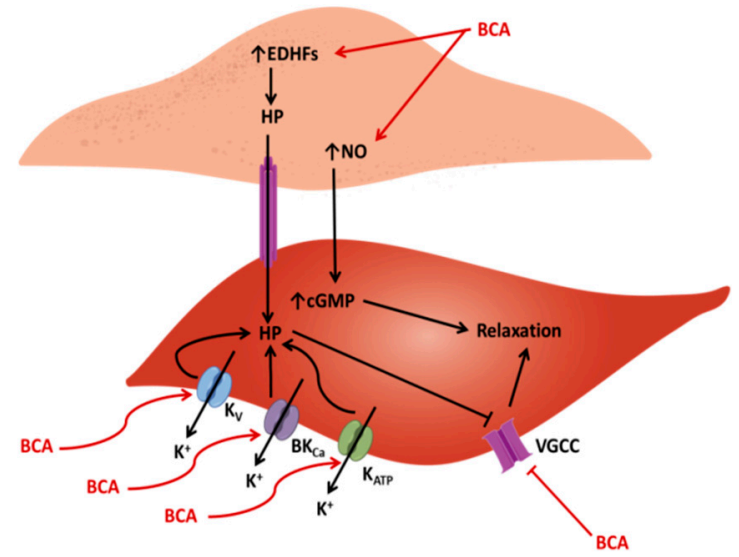

(d)

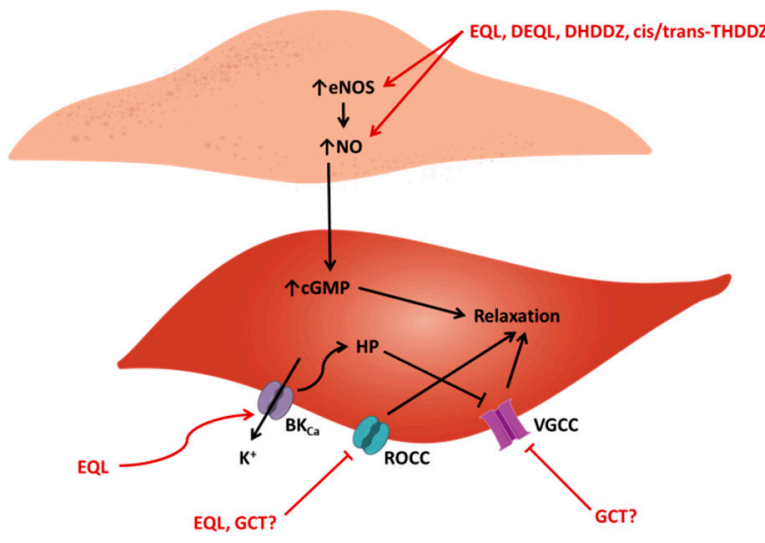

(e)

Figure 2. (a) Proposed vasorelaxation mechanisms for genistein (GNT); (b) proposed vasorelaxation mechanisms for daidzein (DDZ); (c) proposed vasorelaxation mechanisms for formononetin (FMN); (d) proposed vasorelaxation mechanisms for biochanin A (BCA); (e) proposed vasorelaxation mechanisms for glycitein (GCT), equol (EQL), dehydroequol (DEQL), dihydrodaidzein (DHDDZ), and cis- and trans-tetrahydrodaidzein (cis-/trans-THDDZ). 5-HTR—serotonin receptor; $\alpha_{1} \mathrm{R}$ alpha-1 adrenergic receptor; cGMP—cyclic guanosine monophosphate; CFTR—cystic fibrosis transmembrane conductance regulator; CM-calmodulin; CV-1—caveolin-1; CYP450 - cytochrome P450 enzymes; EETs - epoxyeicosatrienoic acids; eNOS—endothelial nitric oxide synthase; EDHFs—endothelium-derived hyperpolarization factors; ER-estrogen receptor; $\mathrm{HP}$-hyperpolarization; MAPK—-mitogen associated protein kinase; NO—nitric oxide; ROCC—receptor-operated calcium channel; TyrK—tyrosine kinase; VGCC—voltage-gated calcium channel. 


\subsection{Endothelium-Dependent Vasorelaxation}

In healthy Wistar rats, vasorelaxation of the aorta and pulmonary artery preconstricted by $\mathrm{PE}$ and $\mathrm{KCl}$ is attenuated by endothelium denudation and by $\mathrm{L}-\mathrm{N}^{\omega}{ }^{\omega}$-nitro arginine methyl ester (L-NAME, i.e., NOS inhibitor) but not by indomethacin (i.e., cyclooxygenase, COX, inhibitor) [149], showing that in this strain and vessels the endothelial prostanoid pathway is not relevant. In female ovariectomized (i.e., low estrogen levels) SpragueDawley rats, genistein restores endothelial-dependent vasorelaxation, which is attributed to a direct increase in eNOS activity [156]. The potentiation of the NO/cGMP pathway is also of relevance for the relaxation of human umbilical veins preconstricted with 5-HT, since L-NAME partially attenuates the response [157].

In healthy Wistar-Kyoto rats, vasorelaxation of PE- and KCl-preconstricted arteries by daidzein is reduced by endothelium denudation, by L-NAME, or indomethacin, showing the importance of endothelial NO/cGMP and prostanoid pathways for this response [150]. In the aortae of Sprague-Dawley and of Wistar rats, daidzein evokes an endotheliumdependent vasorelaxation, both in healthy and in diseased animals. In healthy Wistar rats, daidzein relaxes PE-preconstricted aortae, an effect that is attenuated by L-NAME, by endothelial denudation, but not by ICI 182,780 (fulvestrant, i.e., estrogen receptor antagonist) [149]. In diabetic Wistar rats, daidzein also relaxes PE-preconstricted aortae and potentiates Ach-induced vasorelaxation, an effect that was decreased by L-NAME and indomethacin [158]. In L-NAME hypertensive Wistar rats, daidzein relaxes KClpreconstricted aortae and potentiates Ach-induced relaxation [159]. These studies suggest that daidzein stimulates the endothelial NO/cGMP and prostanoid pathways directly. In the aortae of healthy Sprague-Dawley rats, daidzein again potentiates Ach-induced vasorelaxation [160-162] but does not affect sodium nitroprusside- (SNP, i.e., NO donor) or isoproterenol (i.e., beta adrenergic receptor agonist)-induced vasorelaxation [160,162], suggesting that it increases both basal and stimulated NO secretion. Here, the explanation for this increase in NO is not the modulation of eNOS activity. Rather, it is the decrease in the expression of caveolin- 1 and the increase in the expression of calmodulin that accounts for the increased expression of eNOS [160-162]. In endothelial cells, caveolin-1 binds eNOS and restricts its activity [163], while calmodulin prevents that binding [164]. Therefore, besides stimulating the NO/cGMP pathway directly, daidzein also increases the endothelial availability of eNOS by inhibiting caveolin-1. This modulating effect of caveolin-1 might be attributed to the activation of the estrogen receptor, since estrogen itself upregulates eNOS [165] and downregulates caveolin-1 [166], whereas ovariectomy upregulates caveolin-1 [162]. However, this modulating effect of estrogen in daidzeinmediated vasorelaxation is not verified in all strains, let alone in all vascular beds. For example, in female ovariectomized Sprague-Dawley rats, daidzein prevents the decrease in the endothelial function associated with the decline in the estrogen levels [162].

In Wistar rats, formononetin relaxes PE- and 9,11-Dideoxy-9a, 11a-methanoepoxy prostaglandin $\mathrm{F} 2 \alpha$ (U46619, i.e., thromboxane TXA 2 mimetic)-preconstricted intact aortae, a response which is suppressed by L-NAME, methylene blue (i.e., guanylyl cyclase inhibitor), and endothelium denudation, but not by N-(3-(Aminomethyl)benzyl)acetamidine (1400 W, i.e., inhibitor of the inducible isoform of nitric oxide synthase, iNOS) or propranolol (i.e., nonselective beta adrenergic receptor blocker) [154]. In denuded aortae, methylene blue reduces but does not abolish vasorelaxation, showing that VSM guanylyl cyclase is essential for relaxation and that there are also endothelium-independent mechanisms as well [167]. In Wistar rat mesenteric arteries precontracted by PE and U46619, formononetin-mediated vasorelaxation is partially attenuated by L-NAME and endothelium denudation, whereas indomethacin shows little inhibiting effects. Taken collectively, these results suggest that the endothelial NO/cGMP pathway is important for formononetin-mediated vasorelaxation, although it seems to be site-specific, with the endothelial prostanoids showing relevance in the mesenteric arteries but not in the aorta [154].

In addition to a direct stimulation, formononetin may potentiate the endothelial NO/cGMP pathway by upregulating eNOS at both the mRNA and protein levels [167]. 
In human umbilical vein endothelial cells (HUVECs), formononetin increases NO production and upregulates the expression of eNOS and of neuronal NOS (nNOS) without affecting iNOS [168]. Formononetin is able to increase eNOS expression via activation of the PI3K/PTEN/Akt and MAPK pathways. The enzyme PI3K catalyzes the production of phosphatidylinositol-1,4,5-triphosphate ( $\mathrm{PIP}_{3}$ ) from phosphatidylinositol-4,5-biphosphate $\left(\mathrm{PIP}_{2}\right)$, resulting in the phosphorylation of Akt and other downstream substrates. Phosphatase and tensin homolog deleted on chromosome 10 (PTEN) is a regulatory enzyme that dephosphorylates $\mathrm{PIP}_{3}$, leading to Akt suppression. Formononetin binds PTEN, preventing the suppression of the PI3K/PTEN/Atk pathway, therefore contributing to vasorelaxation [169]. In the rat mesenteric arteries, formononetin-mediated relaxation is partly attributed to the upregulation of eNOS, since it is attenuated by ICI 182,780 [170]. In this vascular bed, formononetin upregulates eNOS through MAPK pathways. The MAPK family is composed of three proteins, ERK, JNK, and p38. ERK alone is unable to upregulate eNOS [171], whereas the combined activation of ERK and JNK do enhance eNOS expression. Protein p38 acts in the opposite direction, suppressing eNOS upregulation [172,173]. Formononetin enhances eNOS expression through activation of the estrogen receptor and both the ERK and JNK downstream proteins [170]. In fact, estrogen can improve vascular endothelial function through upregulation of eNOS and release of NO [174].

In SHRs, biochanin A-induced vasorelaxation is endothelium-dependent, being attenuated by endothelial denudation but not by L-NAME or indomethacin. This suggests the involvement of an EDHF other than NO and prostanoids [175]. In the aortae of twokidney-one-clip (2K1C) renovascular hypertensive rats, biochanin A again appears to induce endothelial-dependent vasorelaxation since endothelium removal decreases the potency of the response. Since biochanin A neither potentiates Ach or SNP-induced vasorelaxation nor is affected by L-NAME, it is probable that vasorelaxation is also mediated by EDHFs [176]. In porcine coronary arteries, biochanin A potentiates vasorelaxation evoked by SNP but not by forskolin (i.e., ROCCs blocker) which suggests that in this vascular bed it raised the intracellular concentration of cGMP [177].

The vasoactive effects of equol, dehydroequol, dihydrodaidzein, cis-tetrahydrodiadzein and trans-tetrahydrodiadzein were examined in the aortae of Sprague-Dawley rats. They showed endothelium-dependent vasodilation, inhibited by endothelium denudation, $\mathrm{N}^{\omega}$ NO-nitro-L-arginine (NOLA, i.e., NOS inhibitor), $1 \mathrm{H}-[1,2,4]$ oxadiazolo [4,3-a]quinoxalin-1one (ODQ, i.e., selective inhibitor of NO-sensitive guanylyl cyclase), and $\mathrm{KCl}$. Contrarily to its effects in most vascular beds, $17 \beta$-estradiol showed endothelium-independent vasodilation [178]. Equol evokes an endothelium-dependent vasorelaxation by stimulating NO release, which is not affected by the ER antagonist ICI 182,780 nor by pertussis toxin (i.e., protein Gi inhibitor) [179]. In a model of endothelial dysfunction, ovariectomized rats were deprived of dietary intake of isoflavones. In these animals, the Ach- and A23187 (i.e., calcium ionophore)-induced endothelium-dependent vasorelaxation were compromised and the administration of equol partially restored that response. Equol did not affect SNP-induced vasorelaxation. Moreover, an ovariectomy decreased the expression of eNOS, which equol partially restored. These results show that equol has predominantly endothelium-dependent vasorelaxant effects, consisting of the potentiation of NO synthesis [180]. In human uterine arteries, equol attenuates PE- but not KCl-induced contraction, suggesting that it blocks ROCCs but not VGCCs [181]. Equol also reverses the endothelial dysfunction caused by ritonavir (i.e., HIV protease inhibitor) in porcine pulmonary arteries. Ritonavir reduces eNOS expression, reduces bradykinin-induced vasorelaxation as well as U46619-induced contraction, whereas equol normalized all these responses [182].

\subsection{Endothelium-Independent Vasorelaxation-The Role of Calcium Channels}

Endothelium-independent vasorelaxation mechanisms have been identified for genistein in several vascular beds. In rat mesenteric arteries, genistein relaxes $\mathrm{NE}-, \mathrm{KCl}-$, and $\mathrm{CaCl}_{2}$ preconstricted vessels, responses which are not affected by L-NAME or indomethacin, ruling out the importance of the endothelial NO/cGMP and prostanoid 
pathways. In this case, genistein seems to act directly in VSM cells. Considering that NE leads to an increase in cyclic adenosine monophosphate (cAMP) levels and that $\mathrm{KCl}$ and $\mathrm{CaCl}_{2}$ both lead to VSM cell depolarization and VGCC activation, it has been proposed that genistein-mediated vasorelaxation involves the protein kinase A (PKA) pathway [183] or the activation of VGCCs [148].

In the basilar artery of New Zealand rabbits, daidzein relaxes $\mathrm{KCl}$ - and uridine 5'triphosphate (UTP)-preconstricted vessels, a response that is not affected by L-NAME, ODQ, 4H-8-bromo-1,2,4-oxadiazolo(3,4-d)benz (b)(1,4)oxazin-1-one (NS2028, i.e., specific soluble guanylyl cyclase), or indomethacin. This suggests that no endothelial mediators, $\mathrm{NO}$, or EDHFs are involved in this response. Given that daidzein relaxes the $\mathrm{CaCl}_{2}-$ preconstricted arteries, it seems to act as a VGCC blocker in VSM cells [155].

Little is known of the vasorelaxation activity of isolated glycitein, given that it has been mainly studied as a part of mixed isoflavone preparations. It is known to relax NE-preconstricted aortae from Wistar Han rats, suggesting it interferes with the calcium influx. In porcine coronary arteries preconstricted by 9,11-Dideoxy-9a, 11a-methanoepoxy prostaglandin F2 $\alpha$ (U46619, i.e., thromboxane $\mathrm{TXA}_{2}$ mimetic), glycitein evokes vasorelaxation in an endothelium-independent way. Furthermore, it attenuates $\mathrm{KCl}-$, calcium chloride $\left(\mathrm{CaCl}_{2}\right)-$, 5-HT-, and U46619-induced constriction of coronary arteries in only a partial way and at high concentrations [177]. More studies are necessary to clarify the vasorelaxation mechanism of glycitein.

Again, in Wistar rats, formononetin relaxes $\mathrm{KCl}$ - and NE-preconstricted aortae, by preventing extracellular calcium influx and by inhibiting the calcium release intracellular stores, respectively. Thus, formononetin also acts on VGCCs and ROCCs on the VSM plasma membrane [184]. Formononetin relaxes $\mathrm{KCl}$ - and $\mathrm{CaCl}_{2}$-preconstricted Wistar mesenteric arteries, again suggesting that it may inhibit VGCCs. Furthermore, because FMN inhibits PE-induced contraction in a calcium-free medium, it inhibits calcium release from intracellular stores in VSM cells, but does not inhibit the extracellular calcium influx through receptor-operated calcium channels. Finally, formononetin does not relax caffeinecontracted vessels, implying that ryanodine receptors are not involved in this intracellular calcium release, but rather inositol 1,4,5-trisphosphate $\left(\mathrm{IP}_{3}\right)$ receptors [154].

In healthy Sprague-Dawley rats, biochanin $\mathrm{A}$ relaxes $\mathrm{PE}-, \mathrm{KCl}-$, and $\mathrm{CaCl}_{2}-$ preconstricted aortae, both intact and denuded alike, suggesting that the effect is endotheliumindependent, involving VSM cells directly [185]. Similarly, in healthy Wistar Han rats, biochanin A relaxes NE-preconstricted aortae, both intact and denuded alike [177]. Since it inhibits NE-, PE-, and KCl-induced contraction, biochanin A may inhibit the influx of extracellular calcium into VSM cells from ROCCs or VGCCs, and/or inhibit the release of calcium from intracellular stores [185]. In endothelium-denuded porcine coronary arteries, biochanin A blocks the effects of Bay K8644 (i.e., L-type calcium channel activator), showing that it blocks the VGCCs on VSM cells [177].

Again, in Sprague-Dawley rats, equol relaxes the carotid artery in an endotheliumindependent manner, given that L-NAME and endothelium denudation did not affect the response. Equol-mediated vasorelaxation was also unaffected by incubation with $\mathrm{U} 46619$ or $\mathrm{KCl}$ with nimodipine (i.e., L-type calcium channel blocker), showing that calcium and potassium channels are not involved in this vascular bed [99]. However, in PE-preconstricted rat aortae, equol-mediated relaxation suggests that it may interfere with the receptor-mediated calcium channels [186].

\subsection{Endothelium-Independent Vasorelaxation-The Role of Potassium Channels}

Different types of potassium ion channels also seem to be involved in genisteinmediated vasorelaxation. In rabbit pulmonary artery cells, genistein is known to block voltage-gated potassium channels [187]. In human umbilical veins preconstricted with 5-HT, genistein-mediated vasorelaxation is decreased by glibenclamide (i.e., $\mathrm{K}_{\text {ATP }}$ channel blocker), suggesting that genistein opens the $\mathrm{K}_{\text {ATP }}$ channels in the VSM cell membrane, leading to hyperpolarization and relaxation [157]. 
The modulation of endothelial and VSM potassium channels are also implicated in endothelial-independent vasorelaxation of the rat aortae and mesenteric arteries. In Wistar rat aortae, daidzein (7 days) potentiates Ach-mediated vasorelaxation, an effect that is attenuated by L-NOLA alone or in combination with hemoglobin. This vasorelaxation is also attenuated by PPOH (i.e., selective inhibitor of the cytochrome P450 isoenzymes epoxygenation reactions) but not by indomethacin. This indicates the existence of endothelium-dependent relaxation mechanisms, which involve both NO/cGMP as well as EDHFs, and probably EETs, products of epoxygenase enzymes that facilitate the opening of the endothelial potassium channels. In fact, daidzein seems to open several potassium channels on VSM and endothelial cells, since charybdotoxin (i.e., large-conductance and intermediate-conductance voltage- and calcium-activated potassium channels, $\mathrm{BK}_{\mathrm{Ca}}$ and $\mathrm{IK}_{\mathrm{Ca}}$, blocker), apamin (i.e., small-conductance calcium-activated potassium channels, $\mathrm{SK}_{\mathrm{Ca}}$, blocker), barium (i.e., inward-rectifier potassium channels, $\mathrm{K}_{\mathrm{IR}}$, blocker), and oubain (i.e., sodium/potassium-ATPase blocker) also attenuate the potentiation of Ach-induced relaxation. In short, daidzein may open the $\mathrm{SK}_{\mathrm{Ca}}$ and $\mathrm{IK}_{\mathrm{Ca}}$ channels on the endothelial cells, probably reinforced by the increased synthesis of EETs. The increased efflux of potassium by these channels can open the $\mathrm{K}_{\mathrm{IR}}$ channels and sodium/potassium-ATPase in VSM cells, leading to their hyperpolarization. The opening of $\mathrm{BK}_{\mathrm{Ca}}$ channels on a VSM membrane can further accentuate this hyperpolarization [188]. In Wistar rat mesenteric arteries, daidzein induces vasorelaxation of $\mathrm{NE}-, \mathrm{KCl}-$, or $\mathrm{CaCl}_{2}$-precontracted mesenteric arteries, suggesting an action that prevents calcium entry, either through receptor-operated or voltage-gated channels. This response is not affected by removal of endothelium nor by indomethacin or L-NAME, besides being also gender-independent, which rules out the influence of $\mathrm{NO} / \mathrm{cGMP}$, prostanoids, and estradiol in modulating the tone of this vascular bed [148]. Posterior studies have highlighted a role for potassium channels, in particular $\mathrm{BK}_{\mathrm{Ca}}$ channels, with the added knowledge that the beta-1 subunit of these channels is important for daidzein vasorelaxation, but only required if the substance is applied from the extracellular side of the membrane [189]. Furthermore, relaxation of NEand $\mathrm{KCl}$-preconstricted mesenteric arteries by daidzein is inhibited by iberiotoxin (i.e., a $\mathrm{BK}_{\mathrm{Ca}}$ channel blocker), charybdotoxin, and by apamin, whereas 4-aminopyridine (i.e., blocker of voltage-gated $\mathrm{K}^{+}$channels, $\mathrm{K}_{\mathrm{V}}$ ), glibenclamide, or barium have no effect on this vasorelaxation. This study revealed that, in mesenteric arteries, daidzein opens the $\mathrm{BK}_{\mathrm{Ca}}$ and $\mathrm{SK}_{\mathrm{Ca}}$ channels in VSM cells, inducing hyperpolarization and relaxation [190]. Finally, one other study also mentioned the relaxation of daidzein in the carotid as well as basilar arteries, but did not explore the underlying mechanisms of relaxation [99].

In Wistar rats, propranolol, ICI 182,780 and mifepristone (i.e., progesterone receptor antagonist) fail to antagonize formononetin-induced aortic vasorelaxation, meaning that the compound does not appear to block the beta adrenergic, estrogen, or progesterone receptors on VSM cells. In contrast, glibenclamide and iberiotoxin suppress formononetin-mediated vasorelaxation in denuded vessels, showing that the opening of potassium channels in VSM cells constitutes a mechanism of endothelial-independent vasorelaxation [167]. In rat mesenteric arteries, the $\mathrm{BK}_{\mathrm{Ca}}$ channel activation appears to be more prominent in intact vessels rather than in denuded ones, suggesting that it has an important role in the endothelium, besides increasing NO secretion [168]. This directly contrasts with the role of the $\mathrm{BK}_{\mathrm{Ca}}$ channels on the rat aorta, whose activation was found only in denuded vessels (VSM cells). These discrepancies may be attributed to anatomical variations in the vasoreactivity to drugs [191]. In particular, endothelium-independent vasoactivity is more pronounced in the smaller resistance arteries, such as the mesenteric arteries, than in large conduits, such as the aorta [192,193], where endothelium-dependent activities prevail.

In healthy Sprague-Dawley rats, biochanin A-mediated vasorelaxation is inhibited by tetraethylammonium (TEA, i.e., $\mathrm{BK}_{\mathrm{Ca}}$ channel blocker) and glibenclamide but not by 4-aminopyridine, suggesting that biochanin A-induced vasorelaxation involves the activation of the $\mathrm{BK}_{\mathrm{Ca}}$ and $\mathrm{K}_{\mathrm{ATP}}$ channels in VSM cells, with consequent hyperpolarization [185]. Similar results were found in the aortae of healthy Wistar-Kyoto rats, where biochanin A 
induced endothelium-independent vasorelaxation by opening the $\mathrm{K}_{\text {ATP }}$ or voltage-gated potassium channels [175]. Similarly, in SHRs, glibenclamide and 4-aminopyridine also attenuated the vasorelaxation response [175]. In the aortae of healthy Sprague-Dawley rats undergoing a sham surgery to the renal artery, biochanin A appears to induce endothelialindependent vasorelaxation since endothelium denudation does not affect the potency of the response. Glibenclamide, TEA, and 4-aminopyridine inhibit vasorelaxation, suggesting that opening of the $\mathrm{BK}_{\mathrm{Ca}}, \mathrm{K}_{\mathrm{ATP}}$, and $\mathrm{K}_{\mathrm{V}}$ channels mediate the endothelium-independent mechanism [176]. In the aorta of $2 \mathrm{~K} 1 \mathrm{C}$ rats endothelium denudation significantly reduces biochanin A-mediated vasorelaxation. Glibenclamide, TEA and 4-aminopyridine also inhibit vasorelaxation, once again showing the involvement of $\mathrm{BK}_{\mathrm{Ca}}, \mathrm{K}_{\mathrm{ATP}}$, and $\mathrm{K}_{\mathrm{V}}$ channels [176]. In the basilar artery of healthy rabbits, biochanin A-mediated vasorelaxation is endothelium-independent, given that the response is similar in intact and in denuded vessels. Because L-NAME, indomethacin, ODQ, and NS2028 do not affect vasorelaxation, it does not seem to involve NO or prostanoids [155]. In the rabbit coronary arteries, biochanin A mediated a concentration-dependent vasorelaxation, which is both sex- and endotheliumindependent, although a mechanism has not been proposed by the authors [38].

In the high insulin-treated carotid artery of male Wistar rats, equol evokes vasorelaxation, a response blocked by iberiotoxin. Moreover, equol attenuated the contraction evoked by TCB2 (i.e., a selective 5- $\mathrm{HT}_{2 \mathrm{~A}}$ receptor agonist) but not by BW723C86 (i.e., selective $5-\mathrm{HT}_{2 \mathrm{~B}}$ receptor agonist). These results suggest that, in this vascular bed, equol prevents 5-HT-mediated vasoconstriction via $\mathrm{BK}_{\mathrm{Ca}}$ channel blockade [194]. In rat basilar arteries, equol evokes vasorelaxation, which is suppressed by paxilline (i.e., selective $\mathrm{BK}_{\mathrm{Ca}}$ channel blocker) and iberiotoxin. This suggests that equol relaxes VSM cells by evoking hyperpolarization [195].

\subsection{Endothelium-Independent Vasorelaxation-The Role of Chloride Channels}

Direct VSM cell hyperpolarization via anion influx is a mechanism of genisteinmediated vasorelaxation present in the rat and mouse aortae. Genistein activates the cystic fibrosis transmembrane conductance regulator (CFTR) chloride channel and increases the flux of anions across the membrane [196]. Moreover, in denuded rat aortae, the vasorelaxant effect of genistein is inhibited by diphenylamine-2-carboxylic acid (i.e., CFTR inhibitor), glibenclamide, H-89 (i.e., selective PKA inhibitor), and bumetanide (i.e., NKCC1 inhibitor). These results strongly suggest that, in rat aortic VSM cells, the genisteinmediated vasorelaxation requires cAMP-dependent phosphorylation of CFTR and the entry of chloride ions via the NKCC1 cotransporter [197].

\subsection{Potentiation of the Protein Kinase A Pathway}

In male Wistar rats, genistein potentiates the relaxation effect of isoproterenol, forskolin, and dibutyryl cAMP in PE-preconstricted aortae. The potentiation of forskolin-induced vasorelaxation is inhibited by theophylline (i.e., phosphodiesterase inhibitor), quinacrine (i.e., phospholipase $\mathrm{A}_{2}$ inhibitor), and iberiotoxin. These results suggest that genistein-induced aortic vasorelaxation also occurs via potentiation of phospholipase $A_{2}$ and PKA pathways. Moreover, the potentiation of isoproterenol vasorelaxation is inhibited by $\alpha$-naphthoflavone and 8-methoxypsoralen (i.e., type I inhibitors of cytochrome P-450), suggesting that EEAs are mediators of this vasorelaxation response [198].

\subsection{Role of Tyrosine Kinase Inhibition}

Several studies have shown the involvement of tyrosine kinase activation in vascular constriction to several inducers and, conversely, the role of tyrosine kinase inhibition in the vasorelaxation response. Tyrosine kinase is known to modulate the action of different types of cation channels, in particular calcium channels. For example, tyrosine kinase modulates the activation of receptor-operated calcium channels in NE-mediated vasoconstriction [199], the calcium influx across nonselective cation channels associated with muscarinic receptors [200], and the conformation of VGCCs in VSM cells, keeping them in an available state 
for activation by depolarization [201]. This enzyme may also be involved in modulating the generation of endothelial NO [202]. Among all isoflavone phytoestrogens, genistein is the only one currently believed to act as a tyrosine kinase inhibitor $[38,160,203]$. In the aorta of spontaneously hypertensive rats (SHRs), tyrosine kinase may play a regulatory role in smooth muscle contraction and endothelium-dependent relaxation [204]. It is thought that in ovariectomized hypertensive rats genistein attenuates constriction of the renal artery by inhibiting tyrosine kinase [205]. In the basilar artery, genistein and tyrphostin 47 (i.e., tyrosine kinase inhibitor) alike attenuate the vasorelaxation to Ach and bradykinin but not to SNP. This suggests that the genistein-mediated vasorelaxation of the basilar artery involves inhibition of tyrosine kinase, which therefore leads to activation of the NO/cGMP pathway [202].

In porcine coronary arteries, genistein enhances the endothelium-independent action of SNP and levcromakalim (i.e., $\mathrm{K}_{\text {ATP }}$ channel activator), but not that of the endotheliumdependent bradikynin [206]. When denuded porcine coronary arteries are dilated by levcromakalin, genistein is able to restore this response in the presence of mexiletine but not lidocaine (i.e., voltage-gated sodium channel blocker). This suggests that the tyrosine kinase inhibiting activity of genistein was partially involved in the restoration of that vasorelaxation via the $\mathrm{K}_{\mathrm{ATP}}$ channels [207].

Genistein is also able to correct vascular hyporesponsiveness, hypotension, and endothelial dysfunction in different contexts. For example, it can correct the vascular hyporeactivity of mesenteric arteries following a hemorrhagic shock. This hyporeactivity is associated with the phosphorylation of the alpha subunit of the $\mathrm{BK}_{\mathrm{Ca}}$ channels, which probably facilitates their opening and, therefore, increases vasorelaxation. By inhibiting tyrosine kinase-mediated phosphorylation of $\mathrm{BK}_{\mathrm{Ca}}$, genistein probably keeps these channels closed, increasing vascular reactivity to contractile stimuli [208]. Administration of genistein suppresses lipopolysaccharide (LPS)-induced long-term hypotension, endothelial dysfunction, and vascular hyporesponsiveness to NE in conscious rats. The main mechanisms underlying this effect are the inhibition of iNOS and a reduction in the tissues' oxidative status [209-211]. Since tyrosine phosphorylation is a step in the LPS pathway, its inhibition by genistein appears to prevent iNOS induction in VSM cells and improve vascular reactivity [209].

Another vascular mechanism of genistein to consider deals with angiotensin II. The signal transduction pathway of angiotensin II leads to the activation of tyrosine kinase [212]. Since genistein itself can inhibit the expression of angiotensin converting enzyme (ACE) [213], it is quite possible that some of its beneficial effects on the vasculature result from the inhibition of both molecular targets.

In several studies in pulmonary arteries and veins, genistein induced vasorelaxation to the contraction induced by several agonists via tyrosine kinase inhibition. It is thought that one of the targets of this tyrosine kinase phosphorylation are regulatory proteins of the Rho kinase enzyme, which modulates the sensitivity of VSM cells to calcium [214]. Finally, recent studies in pulmonary vessels have shown that genistein ameliorates pulmonary hypertension via downregulation of the estrogen receptors $[215,216]$.

\subsection{Inhibition of Rho-Kinase}

In male Sprague-Dawley rats, genistein completely relaxes aortae preconstricted with both full (fluoride) or partial (KCl, phorbol ester, PE or TXA $)$ RhoA/Rho-kinase activators. When Y-27632 (i.e., Rho-kinase inhibitor) is co-administrated with genistein to fluoride-preconstricted aortae, it fails to potentiate the relaxation effect of the genistein itself. Furthermore, genistein decreases phosphorylation of myosin phosphatase target subunit 1 (MYPT1) at Thr855 induced by U46619. Taken together, these results lead to the hypothesis that genistein decreases the Rho-kinase activity, thereby leading to vasorelaxation. Rho-kinase phosphorylates MLCP, decreasing its activity and leading to the buildup of phosphorylated myosin light chains. In addition, Rho-kinase can also phosphorylate myosin light chains directly and independently of the kinase and phos- 
phatase activities. Relaxation of denuded vessels was not inhibited by iberiotoxin, thus ruling out the involvement of $\mathrm{BK}_{\mathrm{Ca}}$ channels [152]. In another study, genistein prevented the lysophosphatidylcholine-induced contraction of rat aortae by inhibition of tyrosine kinase and consequent prevention of an increase in intracellular calcium [217]. In SHRs, genistein potentiates Y-27632 (i.e., Rho kinase inhibitor)-mediated vasorelaxation, which would suggest that an inhibition of Rho kinase was important for this response. However, genistein did not attenuate the increased Rho kinase activity, suggesting that it did not act directly upon this enzyme but probably on tyrosine kinase itself [218]. It is known that the Rho-kinase and tyrosine kinase pathways are intertwined in terms of regulation of vascular tone, although it is presently unclear which pathway exists upstream of the other [152].

In Sprague-Dawley rats, daidzein partially attenuates the aortic contraction to several inductors of RhoA kinase, including PE-, phorbol ester-, $\mathrm{KCl}$-, and $\mathrm{TXA}_{2}$-preconstricted aortas, while exerting full relaxation to fluoride-preconstricted vessels. This marks a difference in its vasorelaxation mechanism with regard to genistein, which shows no difference in the magnitude of relaxation to these inductors. In addition to blocking calcium channels, these results also suggest that daidzein may inhibit RhoA kinase, or phosphorylate of extracellular signal-regulated kinase, a protein kinase C-potentiated inhibitory protein for protein phosphatase type 1 or integrin-linked kinase [152].

\subsection{Activity on Estrogen and Epidermal Growth Factor Receptors}

Among the studied isoflavones, genistein binds to the estrogen receptor with the highest affinity, preferentially to the $\beta$ subtype $[219,220]$, while daidzein and glycitein show lower but comparative binding affinities [221]. Dadizein benefits from a low-affinity binding to estrogen receptor $\alpha / \beta$ subtypes [160]. Vascular estrogen receptors are located in both endothelial and VSM cells [222]. Apparently, the activation of membrane estrogen receptor in VSM cells is linked to the activation of epidermal growth factor receptor (EGFR), which constitutes yet another mechanism for vasorelaxation by genistein. In the aortae of SHRs, genistein potentiates the Ach- and A23187-induced vasorelaxation. This response is not inhibited by ICI 182,780, but is inhibited by MPP (i.e., specific estrogen receptor subtype $\alpha$ antagonist) and by AG1478 (i.e., EGFR inhibitor). Thus, genistein apparently interacts with estrogen receptor subtype $\alpha$ and, via the respective $G$ protein pathway, transactivates EGFR and leads to activation of extracellular signal-regulated kinase. This will ultimately increase eNOS phosphorylation and, consequently, lead to the increase in NO release $[223,224]$.

\subsection{Effect of Adrenergic Receptors}

The chronic administration of formononetin seems to relax the mesenteric arteries in male SHRs by a different mechanism. After the oral administration of formononetin $(50 \mathrm{mg} / \mathrm{kg} /$ day) for 8 weeks, the constriction of mesenteric arteries to PE- and 5-HT, whose receptors are overexpressed in hypertension, is attenuated. This response is associated with a decrease in the expression of the alpha- 1 adrenoceptors and $5-\mathrm{HT}_{2 \mathrm{~A} / 1 \mathrm{~B}}$ receptors at both the mRNA and protein levels, with the accompanying increase in NE and 5-HT levels in plasma. Moreover, the eNOS expression was increased. In addition, although also increased in hypertension, endothelin- 1 and U46619 do not seem to participate in this relaxation, since formononetin fails to relax the arteries when exposed to these substances. Taken together, these results suggest that the chronic administration of formononetin relaxes the mesenteric arteries of SHRs, apparently due to the combined downregulation of the alpha- 1 adrenoceptors and $5-\mathrm{HT}_{2 \mathrm{~A} / 1 \mathrm{~B}}$ receptors and upregulation of eNOS [225]. The downregulation of the alpha- 1 adrenergic receptors is theorized to be attributed to the estrogen-like property of formononetin, since estrogen itself can downregulate the alpha-1 receptors in urethral smooth muscle in rats [226] and formononetin is more potent than estrogen itself at modulating gene expression [227]. 
Table 2. Description and main results of in vitro studies on the vasorelaxant activity of genistein.

\begin{tabular}{|c|c|c|c|c|}
\hline Authors & Compound Concentration & Species and Strain & Type of Vessel & Main Results \\
\hline Laniyonu et al. (1994) [228] & $1-15 \mu \mathrm{M}$ & Male Sprague-Dawley rats & Aorta & $\begin{array}{l}\text { Relaxation of pervanadate-induced but not of } \\
\text { KCl-induced contraction }\end{array}$ \\
\hline Moritoki et al. (1995) [211] & $100 \mu \mathrm{M}$ & Rat (undisclosed strain) & Aorta & $\begin{array}{c}\text { Prevention of LPS-primed, L-arginine-mediated } \\
\text { vasorelaxation }\end{array}$ \\
\hline Filipeanu et al. (1995) [153] & $10^{-6}-10^{-3.5} \mathrm{M}$ & Male Wistar rats & Aorta & Relaxation of PE-preconstricted vessels \\
\hline Herrera et al. (1996) [229] & $10^{-6}-10^{-3} \mathrm{M}$ & Wistar rats (both genders) & Aorta & $\begin{array}{l}\text { Relaxation of NE-, } \mathrm{KCl}-\text {, phorbol } \\
\text { 12-myristate-13-acetate-preconstricted vessels, } \\
\text { responses found to be independent of tyrosine } \\
\text { kinase inhibition }\end{array}$ \\
\hline Watts et al. (1996) [147] & $5 \times 10^{-6} \mathrm{M}$ & Male Sprague-Dawley rats & Carotid artery and aorta (denuded) & $\begin{array}{l}\text { Relaxation of 5-HT-preconstricted denuded } \\
\text { carotid artery but absence of relaxation of } \\
\text { phorbol-12,13-dibutyrate or } \\
\text { KCl-preconstricted vessels }\end{array}$ \\
\hline Duarte et al. (1997) [209] & Genistein (10 mg/kg i.p.) & Male Wistar rats & Aorta & $\begin{array}{c}\text { Inhibition of LPS-mediated hyporresponsiveness } \\
\text { to NE and inhibition of nitrite accumulation } \\
\text { without affecting NOS. }\end{array}$ \\
\hline Satake et al. (1999) [198] & $3 \times 10^{-7}, 10^{-6}, 10^{-5} \mathrm{M}$ & Male Wistar rats & Aorta & $\begin{array}{l}\text { Relaxation of PE-preconstricted vessels. } \\
\text { Potentiation of isoproterenol, forskolin and } \\
\text { dibutyryl cAMP-induced vasorelaxation } \\
\text { Isoproterenol-mediated vasorelaxation was } \\
\text { inhibited by } \alpha \text {-naphthoflavone and by } \\
\text { 8-methoxypsoralen; the potentiation of } \\
\text { forskolin-mediated vasorelaxation was inhibited } \\
\text { by theophylline, iberiotoxin and quinacrine }\end{array}$ \\
\hline Squadrito et al. (2000) [156] & $\begin{array}{l}0.2 \mathrm{mg} / \mathrm{kg} / \text { day administered } \\
\text { subcutaneously for } 4 \text { weeks }\end{array}$ & $\begin{array}{l}\text { Ovariectomized mature female } \\
\text { Sprague-Dawley rats }\end{array}$ & Aorta & $\begin{array}{l}\text { Ovariectomy decreased Ach-induced } \\
\text { vasorelaxation but did not affect SNP response. } \\
\text { Genistein restored endothelial-dependent } \\
\text { vasorelaxation as well as } \mathrm{N}^{\omega} \text {-L-arginine } \\
\text { (L-NMA)-induced contraction. }\end{array}$ \\
\hline Mishra et al. (2000) [149] & $1-100 \mu \mathrm{M}$ & Male Wistar rats & Aorta and pulmonary arteries & $\begin{array}{l}\text { Relaxation of PE and } \mathrm{KCl} \text {-preconstricted vessels, } \\
\text { attenuated by endothelium denudation and } \\
\text { L-NAME but not by indomethacin. }\end{array}$ \\
\hline Suenaga et al. (2002) [217] & $3 \times 10^{-6}, 10^{-5}, 3 \times 10^{-5} \mathrm{M}$ & Male Wistar rats & Aorta & $\begin{array}{l}\text { Prevention of lysophosphatidylcholine-induced } \\
\text { contraction via tyrosine kinase activation. }\end{array}$ \\
\hline
\end{tabular}


Table 2. Cont

\begin{tabular}{|c|c|c|c|c|}
\hline Authors & Compound Concentration & Species and Strain & Type of Vessel & Main Results \\
\hline Valero et al. (2006) [197] & $1-100 \mu \mathrm{M}$ & Male Wistar rats & Aorta (denuded) & $\begin{array}{c}\text { Relaxation, attenuated by } \\
\text { diphenylamine-2-carboxylic acid, glibenclamide, } \\
\text { H-89 and bumetanide. }\end{array}$ \\
\hline $\begin{array}{l}\text { Baluchnejadmojarad et al. } \\
\text { (2008) [231] }\end{array}$ & $\begin{array}{l}1 \mathrm{mg} / \mathrm{kg} / \text { day administered intraperitoneally } \\
\text { for } 4 \text { weeks }\end{array}$ & $\begin{array}{l}\text { Male albino Wistar rats with } \\
\text { streptozotocin-induced diabetes and } \\
\text { controls }\end{array}$ & Aorta & $\begin{array}{l}\text { Potentiation of Ach-mediated vasorelaxation, } \\
\text { partially attenuated by L-NAME and } \\
\text { indomethacin. Attenuation of NE and } \\
\text { KCl-mediated contraction of aortic rings, with } \\
\text { the endothelium removal abolishing the } \\
\text { difference between treated and untreated } \\
\text { diabetic rats }\end{array}$ \\
\hline Galan-Martinez (2008) [151] & 1 to $300 \mu \mathrm{M}$ & Male adult Wistar rats & Aorta (denuded) & Vasorelaxation of $\mathrm{KCl}$-preconstricted vessels. \\
\hline Je et al. (2009) [152] & 0.03 and $0.1 \mathrm{mM}$ & Male Sprague-Dawley rats & Aorta & $\begin{array}{l}\text { Relaxation of PE-, phorbol ester-, } \mathrm{KCl}-\text {, fluoride-, } \\
\text { and } \mathrm{TXA}_{2} \text {-preconstricted vessels, regardless of } \\
\text { endothelial function. Vasorelaxation was not } \\
\text { inhibited by iberiotoxin. }\end{array}$ \\
\hline Nevala et al. (1998) [148] & $10^{-6}-10^{-4} \mathrm{M}$ & $\begin{array}{c}\text { Female and male Wistar rats were } \\
\text { used }\end{array}$ & Mesenteric arteries (intact and denuded) & $\begin{array}{l}\text { Relaxation of NE-, } \mathrm{KCl} \text { - and } \\
\mathrm{CaCl}_{2} \text {-preconstricted vessels, which was } \\
\text { unaffected by L-NAME or indomethacin }\end{array}$ \\
\hline Honore et al. (1997) [232] & $140 \mathrm{mg}$ administered intravenously & Young adult rhesus monkeys & Coronary arteries & $\begin{array}{l}\text { Vasorelaxation in monkeys receiving an } \\
\text { isoflavone-deprived diet. }\end{array}$ \\
\hline Figtree et al. (2000) [38] & 10,20 and $40 \mathrm{mM}$ & $\begin{array}{l}\text { Adult New Zealand white rabbits } \\
\text { (both genders) }\end{array}$ & Coronary arteries & $\begin{array}{l}\text { Relaxation of KCl-preconstricted vessels, either } \\
\text { intact or denuded. The response was unaffected } \\
\text { by L-NAME, indomethacin, glibenclamide, } \\
\text { barium, methylene blue or ICI 182,780. }\end{array}$ \\
\hline
\end{tabular}


Table 2. Cont.

Authors

Compound Concentration

Species and Strain

Pigs

Lee et al. (2003) [206]

$0.1-100 \mu \mathrm{M}$

$10^{-6} \mathrm{M}$

Pigs

Coronary arteries (denuded)

Kimoto et al. (2005) [207]

$10^{-6.5}-10^{-4} \mathrm{M}$

Pigs

Coronary arteries

$\mathrm{Ng}$ et al. (2008) [183]

$1 \mathrm{nM}-0.1 \mathrm{mM}$

Human subjects

Umbilical veins

\section{Main Results}

Relaxation of U46619-preconstricted vessels, not affected by bradykinin or A23187 but potentiated by SNP and cromakalim. Endothelium denudation and tyrphostin 23 did not affect SNP-induced relaxation.

Mexiletine and lidocaine partially abolished the vasorined vasore ATP Channel activator). Genistein restored the evcromakalin-induced vasorelaxation in the presence of mexiletine but not of lidocaine.

Increase in the activity of protein kinase A at high concentration $\left(10^{-4.5} \mathrm{M}\right)$. At a lower concentration $\left(10^{-5.5} \mathrm{M}\right)$ it failed to increase PKA concentration $\left(10^{-5.5} \mathrm{M}\right)$ it failed to increase PKA
activity, unless together with forskolin. SQ22536 (i.e., adenylyl cyclase inhibitor) blocked the genistein-mediated potentiation of PKA, unlike NF 449 (i.e. P2X1 receptor antagonist)

\begin{tabular}{|c|c|c|c|c|}
\hline Pinna et al. (2019) [157] & $1 \mathrm{nM}-0.1 \mathrm{mM}$ & Human subjects & Umbilical veins & $\begin{array}{l}\text { Relaxation of 5-HT-preconstricted intact vessels, } \\
\text { attenuated by L-NAME, and completely } \\
\text { abolished by L-NAME and glibenclamide. }\end{array}$ \\
\hline Kitazono et al. (1998) [202] & $10^{-6}$ or $3 \times 10^{-6} \mathrm{M}$ & Male Sprague-Dawley rats & Basilar artery & $\begin{array}{l}\text { Attenuation of Ach and bradykinin-mediated } \\
\text { vasorelaxation, whereas SNP-mediated } \\
\text { relaxation was not affected. }\end{array}$ \\
\hline Kitayama et al. (2002) [218] & $1 \mathrm{mg} / \mathrm{kg}$ chow for 2 months & Male SHR & Basilar artery & $\begin{array}{l}\text { Potentiation of Ach- and Y-27632-mediated } \\
\text { vasorelaxation in SHR. No attenuation of the } \\
\text { increased Rho kinase activity. }\end{array}$ \\
\hline
\end{tabular}

Table 3. Description and main results of in vitro studies on the vasorelaxant activity of daidzein.

\begin{tabular}{|c|c|c|c|c|}
\hline Authors & Compound Concentration & Species and Strain & Type of Vessel & Main Results \\
\hline Mishra et al. (2000) [149] & 10 and $100 \mu \mathrm{M}$ & Adult male Wistar rats & Aorta & $\begin{array}{l}\text { Relaxation of PE-preconstricted vessels, attenuated } \\
\text { by endothelium denudation and by L-NAME. }\end{array}$ \\
\hline Woodman et al. (2004) [188] & $\begin{array}{l}0.2 \mathrm{mg} / \mathrm{kg} / \text { day administered } \\
\text { subcutaneously for } 7 \text { days }\end{array}$ & Male Sprague-Dawley rats & Aorta & $\begin{array}{l}\text { Potentiation of Ach-induced vasorelaxation, } \\
\text { attenuated by L-NOLA, PPOH, barium, and oubain }\end{array}$ \\
\hline
\end{tabular}


Table 3. Cont

\begin{tabular}{|c|c|c|c|c|}
\hline Authors & Compound Concentration & Species and Strain & Type of Vessel & Main Results \\
\hline Ajay et al. (2003) [150] & $0.3 \mathrm{mM}$ & Male Wistar-Kyoto rats & Aorta (intact) & $\begin{array}{l}\text { Relaxation of PE and } \mathrm{KCl}-\text { preconstricted vessels, } \\
\text { reduced by L-NAME and indomethacin }\end{array}$ \\
\hline Je et al. (2009) [152] & $0.01,0.03$ and $0.1 \mathrm{mM}$ & Male Sprague-Dawley rats & Aorta & $\begin{array}{l}\text { Relaxation of PE-, } \mathrm{KCl}-\text {, fluoride-, and phorbol } \\
\text { ester-preconstricted vessels }\end{array}$ \\
\hline Sharma et al. (2012) [162] & $\begin{array}{c}0.2,0.4 \text { or } 0.6 \mathrm{mg} / \mathrm{kg} / \text { day administered } \\
\text { subcutaneously for } 7 \text { days }\end{array}$ & Female Sprague-Dawley ovariectomized rats & Aorta & $\begin{array}{l}\text { Potentiation of Ach-, but not of SNP-induced, } \\
\text { vasorelaxation. Increased expression of eNOS, } \\
\text { calmodulin, and decreased expression of } \\
\text { caveolin-1, which prevented ovariectomy-induced } \\
\text { vascular dysfunction. }\end{array}$ \\
\hline Roghani et al. (2013) [158] & $\begin{array}{c}5 \text { or } 10 \mathrm{mg} / \mathrm{kg} \text { administrated by gavage } \\
\text { for } 7 \text { weeks }\end{array}$ & $\begin{array}{c}\text { Healthy and streptozotocin-induced diabetic } \\
\text { Male Wistar rats }\end{array}$ & Aorta & $\begin{array}{c}\text { Relaxation of PE-preconstricted vessels, abolished } \\
\text { by endothelium denudation. In treated animals, } \\
\text { Ach-induced vasorelaxation was also higher, but } \\
\text { L-NAME and indomethacin attenuated } \\
\text { this response. }\end{array}$ \\
\hline Prawez et al. (2015) [159] & $\begin{array}{l}0.5 \mathrm{mg} / \mathrm{kg} \text { administered subcutaneously } \\
\text { for } 6 \text { weeks }\end{array}$ & L-NAME hypertensive male Wistar-rats & Aorta & $\begin{array}{c}\text { Relaxation of KCl-preconstricted vessels. } \\
\text { Potentiation of Ach-induced vasorelaxation. } \\
\text { Decreased potency of SNP-induced vasorelaxation. }\end{array}$ \\
\hline Sobey et al. (2004) [161] & $\begin{array}{l}0.2 \mathrm{mg} / \mathrm{kg} / \text { day administered } \\
\text { subcutaneously for } 7 \text { days }\end{array}$ & Male Sprague-Dawley rats & Carotid and basilar arteries & $\begin{array}{l}\text { Potentiation of Ach-induced vasorelaxation. } \\
\text { Potentiation of L-NNA-induced contraction. } \\
\text { Expression of caveolin-1 decreased, expression of } \\
\text { calmodulin increased and expression of eNOS } \\
\text { was unaffected. }\end{array}$ \\
\hline Jackman et al. (2007) [99] & $10^{-7}-10^{-3} \mathrm{M}$ & Adult Sprague-Dawley rats (both genders) & Carotid and basilar arteries & $\begin{array}{l}\text { Relaxation of carotid arteries and vasodilation } \\
\text { (in vivo) of basilar arteries. }\end{array}$ \\
\hline Zhang et al. (2010) [189] & $10^{-7}-10^{-4} \mathrm{M}$ & Male Sprague-Dawley rats & Basilar artery & $\begin{array}{l}\text { Vasorelaxation, inhibited by paxilline, but } \\
\text { enhanced by NS1619 }\end{array}$ \\
\hline Torregrosa et al. (2003) [155] & $10^{-7}-10^{-4} \mathrm{M}$ & New Zealand White male rabbits & Basilar arteries & $\begin{array}{l}\text { Relaxation of } \mathrm{KCl} \text { or UTP-precontracted vessels, } \\
\text { unaffected by endothelial denudation or by } \\
\text { L-NAME, ODQ, or NS2028 }\end{array}$ \\
\hline Nevala et al. (1998) [148] & $10^{-6}-10^{-4} \mathrm{M}$ & Wistar rats (both genders) & Mesenteric arteries & $\begin{array}{l}\text { Relaxation of } \mathrm{NE}, \mathrm{KCl} \text { or } \mathrm{CaCl}_{2} \text { precontracted } \\
\text { vessels, unaffected by endothelium denudation, } \\
\text { indomethacin or L-NAME }\end{array}$ \\
\hline Nevala et al. (2001) [190] & $10-100 \mathrm{mM}$ & Female Wistar rats & Mesenteric arteries (denuded) & $\begin{array}{c}\text { Relaxation of NE- and KCl-preconstricted vessels, } \\
\text { attenuated by iberiotoxin, charybdotoxin, } \\
\text { and apamin }\end{array}$ \\
\hline
\end{tabular}


Table 4. Description and main results of in vitro studies on the vasorelaxant activity of formononetin.

\begin{tabular}{|c|c|c|c|c|}
\hline Authors & Compound Concentration & Species and Strain & Type of Vessel & Main Results \\
\hline Wu et al. (2010) [167] & $10 \mu \mathrm{M}, 100 \mu \mathrm{M}$, and $1 \mathrm{mM}$ & Male Sprague-Dawley rats & Aorta & $\begin{array}{l}\text { Relaxation of intact vessels, suppressed } \\
\text { by L-NAME and methylene blue but not } \\
\text { by } 1400 \mathrm{~W} \text { or propranolol. In } \\
\text { endothelium-denuded vessels, } \\
\text { vasorelaxation was attenuated by } \\
\text { methylene blue, glibenclamide, or } \\
\text { iberiotoxin. Enhancement of eNOS } \\
\text { expression and activity. }\end{array}$ \\
\hline Zhao et al. (2012) [184] & $10-100 \mu \mathrm{M}$ & Male Sprague-Dawley rats & Aorta & $\begin{array}{l}\text { Relaxation of } \mathrm{KCl} \text { - and } \\
\text { NE-preconstricted vessels }\end{array}$ \\
\hline Li et al. (2018) [169] & $10^{-8}-10^{-3} \mathrm{M}$ & Sprague-Dawley rats & Aorta (intact and denuded) & $\begin{array}{l}\text { Relaxation of } \mathrm{KCl} \text {-preconstricted vessels, } \\
\text { suppressed by endothelium denudation } \\
\text { and by L-NAME }\end{array}$ \\
\hline Sun et al. (2011) [154] & $1-300 \mu \mathrm{M}$ & Sprague-Dawley rats & $\begin{array}{l}\text { Mesenteric, renal, basilar, } \\
\text { coronary and aortic arteries } \\
\quad \text { (intact and denuded) }\end{array}$ & $\begin{array}{c}\text { Relaxation of PE- or } \\
\text { U46619-preconstricted vessels, attenuated } \\
\text { by endothelium denudation }\end{array}$ \\
\hline Sun et al. (2016) [170] & $1-10 \mu \mathrm{M}$ & Male Sprague-Dawley rats & Mesenteric arteries & $\begin{array}{c}\text { Vasorelaxation, attenuated by ICI } 182780 . \\
\text { Expression of eNOS increased via ERK } \\
\text { and JNK activation. }\end{array}$ \\
\hline Tseng et al. (2016) [168] & $1 \mathrm{nM}-100 \mu \mathrm{M}$ & Male Sprague-Dawleyrats & Mesenteric arteries & $\begin{array}{l}\text { Relaxation of intact vessels, suppressed } \\
\text { by L-NAME and glibenclamide }\end{array}$ \\
\hline Sun et al. (2013) [225] & $50 \mathrm{mg} / \mathrm{kg}$ administered orally for 8 weeks & Male SHRs & Mesenteric arteries & $\begin{array}{l}\text { Attenuation of NE or 5-HT-induced } \\
\text { vasoconstriction. Potentiation of } \\
\text { Ach-induced vasodilation. Expression of } \\
\text { alpha-1 adrenergic and 5-HT } \mathrm{HT}_{2 \mathrm{~A} / 1 \mathrm{~B}} \\
\text { receptors in VSM cells decreased. }\end{array}$ \\
\hline
\end{tabular}


Table 5. Description and main results of in vitro studies on the vasorelaxant activity of biochanin A.

\begin{tabular}{|c|c|c|c|c|}
\hline Authors & Compound Concentration & Species and Strain & Type of Vessel & Main Results \\
\hline Choi et al. (2014) [176] & $10^{-7}-10^{-4} \mathrm{M}$ & $\begin{array}{l}\text { Male Sprague-Dawley rats } \\
\text { subjected to } 2 \mathrm{~K} 1 \mathrm{C} \text {-induced } \\
\text { renovascular hypertension }\end{array}$ & Aorta & $\begin{array}{l}\text { Endothelium-dependent vasorelaxation was } \\
\text { attenuated by endothelium denudation, by } \\
\text { glibenclamide, TEA and by 4-aminopyridine }\end{array}$ \\
\hline Wang et al. (2005) [185] & $10^{-9}-10^{-4} \mathrm{M}$ & Sprague-Dawley rats & Aorta & $\begin{array}{c}\text { Relaxation of } \mathrm{PE}-, \mathrm{KCl}-\text {, and } \mathrm{CaCl}_{2} \text {-preconstricted } \\
\text { vessels, intact and endothelium-denuded, attenuated } \\
\text { by TEA and glibenclamide but not } \\
\text { by } 4 \text {-aminopyridine }\end{array}$ \\
\hline \multirow[b]{2}{*}{ Migko et al. (2020) [177] } & $10^{-7}-10^{-3} \mathrm{M}$ & Wistar Han rats & Aorta & Relaxation of NE-preconstricted vessels. \\
\hline & $3 \times 10^{-6}-3 \times 10^{-5} \mathrm{M}$ & Pigs & Coronary arteries & $\begin{array}{l}\text { Relaxation of } \mathrm{KCl}-, \mathrm{CaCl}_{2-}, 5-\mathrm{HT}-\text {, and } \\
\mathrm{U} 46619 \text {-preconstricted vessels. Endothelium } \\
\text { denudation did not affect relaxation of } \\
\text { U46619-preconstricted vessels. Potentiation of } \\
\text { vasorelaxation by SNP but not by forskolin. }\end{array}$ \\
\hline Figtree et al. (2000) [38] & 3,10 and $30 \mu \mathrm{M}$ & $\begin{array}{l}\text { Adult male or non-pregnant female } \\
\text { New Zealand white rabbits }\end{array}$ & Coronary arteries & $\begin{array}{c}\text { Relaxation, independent of gender, of intact and } \\
\text { denuded vessels }\end{array}$ \\
\hline
\end{tabular}


Table 6. Description and main results of in vitro studies on the vasorelaxant activity of equol and other metabolites.

\begin{tabular}{|c|c|c|c|c|}
\hline Authors & Compound Concentration & Species and Strain & Type of Vessel & Main Results \\
\hline Chin-Dusting et al. (2001) [178] & $\begin{array}{l}\text { Dihydrodaidzein, cis-, and } \\
\text { trans-tetrahydrodaidzein, } \\
\text { dehydroequol }(1 \mu \mathrm{g} / \mathrm{mL})\end{array}$ & Male Sprague-Dawley rats & Aorta & $\begin{array}{l}\text { Vasorelaxation, inhibited by endothelium } \\
\text { denudation, by L-NOLA, ODQ, or KCl }\end{array}$ \\
\hline Joy et al. (2006) [179] & Equol $(0.03-15 \mu \mathrm{M})$ & Sprague-Dawley rats & Aorta & $\begin{array}{l}\text { Vasorelaxation by stimulation of NO release, a } \\
\text { response that is unaffected by ICI } 182,780 \text { or } \\
\text { pertussis toxin }\end{array}$ \\
\hline Ohkura et al. (2015) [180] & $\begin{array}{l}\text { Equol (200 mg/day for } 5 \text { weeks via } \\
\text { osmotic pump) }\end{array}$ & $\begin{array}{l}\text { Isoflavone-deficient ovariectomized } \\
\text { Sprague-Dawley rats }\end{array}$ & Carotid arteries & $\begin{array}{l}\text { Restoration of Ach-mediated vasorelaxation, which } \\
\text { was suppressed by } N^{\omega} \text {-monomethyl-L-arginine } \\
\text { acetate (L-NMMA) }\end{array}$ \\
\hline Kim et al. (2015) [181] & Equol $\left(10^{-11}-10^{-6} \mathrm{M}\right)$ & Human subjects & Uterine arteries & $\begin{array}{l}\text { Relaxation of PE-, but not of } \\
\mathrm{KCl} \text {-preconstricted vessels }\end{array}$ \\
\hline Cheng et al. (2010) [182] & Equol $(0.1,1$, and $10 \mu \mathrm{M})$ & Pigs & Pulmonary arteries & $\begin{array}{l}\text { Restoration of ritonavir-induced reduction in } \\
\text { eNOS expression. Restoration of } \\
\text { bradykinin-mediated vasorelaxation. }\end{array}$ \\
\hline
\end{tabular}




\section{Effect on Blood Pressure and Blood Flow}

Studies conducted both in animals and in humans have shown that isoflavones are able to reduce blood pressure by modulating several cardiovascular activities. Apart from their vasorelaxant activity, isoflavones are also able to modulate baroreceptor sensitivity, catecholamine synthesis at the adrenal medulla, as well as to affect the renin-angiotensinaldosterone (RAA) endocrine axis. Most studies published thus far, however, have assessed the effect of mixtures of isoflavones, which hinders the knowledge of which bioactive compounds may be responsible for the observed beneficial effects and whether those effects are cumulative or not. Besides the chemical heterogeneity of soy-based products, several other factors contribute to the variability in terms of results, such as study type and duration, inclusion and non-inclusion criteria, source of isoflavones (foodstuffs, extracts), and the profile of intestinal metabolism (equol producers, non-producers). Several systematic reviews and meta-analyses have been conducted, hoping to shed light on the effects of isoflavone supplementation on blood pressure, but only a few studies so far have focused on the effects of isolated compounds. Table 7 summarizes the main findings of the studies that assessed the blood pressure lowering effects of isolated isoflavones in animals and in humans.

In stroke-prone male SHRs, the chronic administration of genistein $(0.6 \mathrm{mg} / \mathrm{g}$ diet for 7 weeks) attenuated the increase of blood pressure caused by dietary sodium chloride, a response blunted by hexamethonium (i.e., ganglion blocker). During this intervention, an increase in NO plasma levels was also noted. These results suggest that the hypotensive effect of genistein is due to an increased production of $\mathrm{NO}$ at the vascular endothelium and/or due to the modulation of an autonomic nervous system response [233]. In ovariectomized SHRs, the chronic administration of genistein $(10 \mathrm{mg} / \mathrm{kg} /$ day by gavage for 5 weeks) reduces the systolic blood pressure [230]. When administered intravenously to the brachial artery of healthy human subjects, genistein increases forearm blood flow with a similar potency to that of $17 \beta$-estradiol. It also potentiated the vasodilation response to Ach but not to SNP, and its effect was attenuated by $\mathrm{N}^{\omega}$-monomethyl-L-arginine acetate (L-NMMA, i.e., NOS inhibitor), suggesting again that genistein increased the endothelial secretion of NO [234]. In post-menopausal women, the chronic ingestion of genistein (54 mg/day for 1 year) significantly improves flow-mediated dilation of the brachial artery with a similar potency to an estrogen/progestin scheme, in addition to lowering the plasma endothelin-1 levels $[235,236]$.

In L-NAME-induced hypertensive rats, administration of daidzein $(0.5 \mathrm{mg} / \mathrm{kg}$ subcutaneous) for 6 weeks reduces the mean blood pressure in comparison to untreated animals. Moreover, thoracic aortae from daidzein-treated rats showed higher dilation to Ach in comparison to untreated animals [159]. Daidzein sulfates show a hypotensive effect in SHR at different concentrations $(20 \mathrm{mg} / \mathrm{kg}$ and $40 \mathrm{mg} / \mathrm{kg})$, with single or multiple (1/day for 2 weeks) oral administrations. Daidzein $(20 \mathrm{mg} / \mathrm{kg}$ ) decreases blood pressure in multidose (more slowly than for sulfates) but not in single dose administrations [237]. In a study performed in pre-hypertensive and untreated hypertensive, post-menopausal and equolproducing female subjects, daidzein $(63 \mathrm{mg})$ taken orally for 6 months neither changed their blood pressure nor improved their flow-mediated dilation [98]. When daidzein is administered intravenously to the brachial artery of healthy young subjects, it fails to change forearm blood flow [234].

The chronic administration of formononetin $(80 \mathrm{mg} /$ day for 5 weeks) to normotensive human subjects does not change blood pressure or improve flow-mediated dilation [12]. When formulated in enteric-coated microparticles and administered to hypertensive ovariectomized rats, biochanin A $(10 \mathrm{mg} / \mathrm{kg}$, p.o. for 1 week) significantly decreases the systolic, diastolic, and mean blood pressure [238]. This effect seems to be largely attributed to an endothelium-dependent decrease in peripheral resistance, as coadministration with L-NAME prevented this hypotensive effect [238]. When administered to SHRs for 8 weeks, formononetin $(50 \mathrm{mg} / \mathrm{kg} /$ day) lowers blood pressure and shows endothelium-dependent vasodilation [225]. The chronic administration of biochanin A 
( $80 \mathrm{mg} /$ day for 5 weeks) to normotensive human subjects does not change the blood pressure nor improve the flow-mediated dilation [12].

The effect of several isoflavone metabolites on blood pressure and perfusion was also examined. The topical administration of equol to surgically exposed basilar arteries in Sprague-Dawley rats results in a weak vasodilation and antioxidant effect. Presumably, equol might react with reactive oxygen species (ROS) and prevent a decline in endothelial NO levels [99]. In deoxycorticosterone acetate/salt-induced hypertensive rats, the chronic administration of equol ( 10 and $20 \mathrm{mg} / \mathrm{kg}$ for 5 weeks) reduces their blood pressure, presumably by increasing endothelial NO synthesis and inhibiting RAA axis [239]. When dehydroequol is administered intravenously to the brachial artery in healthy human males, forearm blood flow increases, a response that is blunted by L-NMMA [240]. The effect of trans-tetrahydrodaidzein (i.e., a metabolite of daidzein and formononetin) was examined in humans. In middle-aged subjects with significant cardiovascular risk (overweight, dyslipidemia, and impaired glucose metabolism), the oral supplementation with transtetrahydrodaidzein $(1 \mathrm{~g} /$ day for 5 weeks) significantly reduced blood pressure and arterial stiffness [241].

In humans consuming soy-free diets, the plasma concentration of isoflavones lies in the nanomolar range, typically under $40 \mathrm{nM}$ [242]. The ingestion of dietary soy increases the plasma concentration up to the micromolar range $(7-8 \mu \mathrm{M})$, for example in East Asian populations and in vegetarians, as does the ingestion of soy-based foodstuffs and supplements [21-23]. One study in healthy subjects has shown that, after the ingestion of a commercially available soy protein drink containing $37 \mathrm{mg}$ genistein, the plasma concentration of genistein reaches levels of approximately $2 \mathrm{mM}$ [38]. Given that the vasorelaxation effects attributed to isoflavones are mostly obtained with plasma concentrations in the micromolar range, it becomes apparent that isolated isoflavones should only exert vasodilation in vivo when supplemented in concentrated drinks/beverages. In contrast, when absorbed through long-term dietary intake, these beneficial vascular effects are probably attributed to a synergistic action of different isoflavones in addition to a possible modulation of the intestinal isoflavone metabolism by intestinal flora.

\subsection{Effect on the Renin-Angiotensin-Aldosterone Axis}

The RAA axis consists of an endocrine system that contributes to blood pressure regulation by modulating peripheral vascular resistance. When kidney perfusion pressure decreases, the kidney granular cells increase the secretion of the enzyme renin. In the bloodstream renin converts the liver peptide angiotensinogen to angiotensin I; both of these are biologically inactive. Then, angiotensin I is converted to angiotensin II by ACE, an enzyme expressed in the endothelial cells of pulmonary and renal circulations. Angiotensin II can be converted to angiotensin-(1-7) by ACE2 and to angiotensin III by aminopeptidase A (APA). Finally, angiotensin III is converted to angiotensin IV by aminopeptidase D. The several mediators of this pathway exert many different functions in the organism. At the vascular level, angiotensin II and angiotensin III are vasoconstrictor mediators, whereas angiotensin-(1-7) and angiotensin IV produce vasodilation [243].

Several isoflavones interfere with the RAA axis. Genistein inhibits the expression of ACE in a concentration-dependent way in the serum of Wistar [244] as well as in the serum, aorta, and aortic endothelial cells of Sprague-Dawley rats [213]. In the latter, this response is blocked by tamoxifen (i.e., nonspecific estrogen receptor antagonist), showing that this effect is mediated by the estrogen receptor. Moreover, the compound PD98059 (i.e., ERK1/2 phosphorylation inhibitor) abolished this response, also showing that genistein inhibits ACE through activation of the ERK1/2 pathway [213]. When incubated with aortic endothelial cells from stroke-prone SHRs, genistein suppressed the expression of the angiotensin II type 1 receptor in a concentration- and time-dependent manner [245]. In different animal models genistein has produced different results regarding its capacity to modulate the RAA axis in vivo. When administered in the diet $(0.6 \mathrm{mg} / \mathrm{g}$ diet for 7 weeks) of stroke-prone SHRs, it failed to significantly change the levels of renin and aldosterone [233]. However, a 
two-day pretreatment with genistein $(25 \mathrm{mg} / \mathrm{kg}$ intravenously) prevents the hypertensive response of angiotensin I, accentuates the hypotensive response of bradykinin, but does not alter the hypertensive effect of angiotensin II [244]. Similarly, when administered intravenously to conscious Sprague-Dawley rats, it fails to suppress the hypertensive response to angiotensin II [246]. Daidzein is known to inhibit ACE activity in vitro and to display significant hypotensive effects in vivo. The intravenous administration of daidzein $(25 \mathrm{mg} / \mathrm{kg}$ ) attenuates the increase in blood pressure induced by angiotensin I in healthy Wistar rats [247]. Daidzein inhibits ACE activity in vitro in a concentration-dependent manner. Rat plasma samples treated with daidzein (3-300 $\mu \mathrm{mol} / \mathrm{L})$ show significantly lower ACE activity [247]. Similar concentrations were previously found to inhibit ACE activity in rat aortic endothelial cells [213]. Formononetin does not seem to affect the RAA axis in vivo. When administered chronically ( $50 \mathrm{mg} / \mathrm{kg} /$ day for 8 weeks), it did not significantly change the serum concentrations of renin, angiotensin II, and aldosterone [225]. In deoxycorticosterone acetate salt-induced hypertensive rats, the chronic administration of equol (10 and $20 \mathrm{mg} / \mathrm{kg}$ for 5 weeks) decreased ACE activity and expression, increased ACE2 expression, and decreased plasma angiotensin I and aldosterone, thus showing an inhibitory activity on the RAA axis with a potency equivalent to that of lisinopril (i.e., ACE inhibitor) [239].

\subsection{Effect on Baroreceptor Sensitivity}

Isoflavones are also able to interfere with the blood pressure-regulating mechanisms. To date, the only isoflavone to be able to modulate baroreceptor sensitivity was genistein. At concentrations of 50-200 $\mu \mathrm{mol} / \mathrm{L}$, genistein inhibits the carotid baroreceptor in male anesthetized Sprague-Dawley rats. This inhibition is not blocked by L-NAME but rather by Bay K8644 or by sodium orthovanadate (i.e., inhibitor of tyrosine phosphatase). This suggests that genistein inhibits the baroreceptor by inhibiting tyrosine kinase and inducing vasorelaxation as well as by blocking calcium influx into the baroreceptor neurons [248]. Besides acting peripherally to modulate baroreceptor sensitivity, the topical application of genistein on the medulla of anesthetized Sprague-Dawley rats reduces PE-induced reflex bradycardia [249].

\subsection{Effect on Catecholamine Synthesis}

Genistein and daidzein are known to affect catecholamine synthesis. Genistein (0.1-10 $\mu \mathrm{M})$ is able to increase the uptake of noradrenaline into SK-N-SH and COS-7 cells [250]. Daidzein seems to display a dual effect on catecholamine secretion. At low concentrations (10-100 nM), daidzein stimulates catecholamine synthesis on bovine medullary cells by increasing the tyrosine hydroxylase activity. At high concentrations $(\geq 1 \mu \mathrm{M})$, however, daidzein inhibits catecholamine synthesis [251].

\subsection{Possible Connection between Effects on Immunity and Blood Pressure}

Isoflavones are also known to affect immune function in a variety of ways. They are able to modulate the numbers of circulating immune cells, such as eosinophils and lymphocytes as well as the levels of lymphocytes in the thymus and spleen. They can also modulate the maturation and reactivity of immune cells, such as natural killer, T lymphocyte, macrophage, and dendritic cells, as well as modulate cytokine production [252]. Although there are currently no studies providing a direct connection between the immune modulation activity of isoflavones and blood pressure regulation, it is possible that such an activity may directly and indirectly affect vascular tone, vascular permeability, and even changes in vascular histology. 


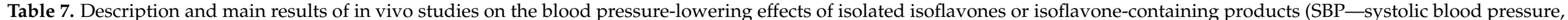
$\mathrm{DBP}$-diastolic blood pressure, $\mathrm{MBP}$ - mean blood pressure).

\begin{tabular}{|c|c|c|c|c|}
\hline Authors & $\begin{array}{l}\text { Compound Concentration/Dosage } \\
\text { and Duration of Treatment }\end{array}$ & Animal Species and Strain & $\begin{array}{l}\text { Blood Pressure Measurement } \\
\text { Technique }\end{array}$ & Main Results \\
\hline Vera et al. (2007) [230] & $\begin{array}{l}\text { Genistein }(10 \mathrm{mg} / \mathrm{kg} / \text { day }) \text { by } \\
\text { gavage for } 5 \text { weeks }\end{array}$ & Ovariectomized SHRs & Tail-cuff plethysmography & Reduction of SBP after 5 weeks \\
\hline Prawez et al. (2015) [159] & $\begin{array}{l}\text { Daidzein }(0.5 \mathrm{mg} / \mathrm{kg}) \text { administered } \\
\text { subcutaneously for } 6 \text { weeks }\end{array}$ & L-NAME-induced hypertensive rats & Invasive pressure transducer & $\begin{array}{l}\text { Reduction of MBP in comparison to } \\
\text { untreated animals }\end{array}$ \\
\hline Cao et al. (2006) [237] & $\begin{array}{l}\text { Daidzein sulfates }(20 \mathrm{mg} / \mathrm{kg} \text { and } \\
40 \mathrm{mg} / \mathrm{kg} \text { ) with a single or multiple } \\
\text { (1/day for } 2 \text { weeks) } \\
\text { oral administrations }\end{array}$ & SHRs & Tail-cuff plethysmography & $\begin{array}{l}\text { Blood pressure reduction with single or } \\
\text { multiple administrations. Daidzein } \\
\text { decreases blood pressure in multidose } \\
\text { (more slowly than for sulfates) but not in } \\
\text { single dose administrations }\end{array}$ \\
\hline Liu et al. (2015) [98] & $\begin{array}{l}\text { Daidzein }(63 \mathrm{mg}) \text { taken orally for } \\
6 \text { months }\end{array}$ & $\begin{array}{l}\text { Pre-hypertensive and untreated } \\
\text { hypertensive post-menopausal subjects }\end{array}$ & $\begin{array}{l}\text { Portable device, calibrated by a mercury } \\
\text { sphygmomanometer }\end{array}$ & $\begin{array}{l}\text { No change in blood pressure. No } \\
\text { improvement in flow-mediated dilation } \\
\text { was observed. }\end{array}$ \\
\hline Sachdeva et al. (2016) [238] & $\begin{array}{c}\text { Biochanin A }(10 \mathrm{mg} / \mathrm{kg} \text {, p.o. for } \\
1 \text { week })\end{array}$ & Hypertensive ovariectomized rats & Tail-cuff plethysmography & $\begin{array}{c}\text { Reduction of SBP, DBP and MBP, blunted } \\
\text { by L-NAME }\end{array}$ \\
\hline Sun et al. (2013) [225] & $\begin{array}{l}\text { Formononetin }(50 \mathrm{mg} / \mathrm{kg} / \text { day for } \\
8 \text { weeks })\end{array}$ & SHRs & Tail-cuff plethysmography & $\begin{array}{l}\text { Blood pressure reduction and } \\
\text { endothelium-dependent vasodilation }\end{array}$ \\
\hline Palanisamy and Venkataraman (2013) [253] & $\begin{array}{l}\text { Genistein }(1 \mathrm{mg} / \mathrm{kg} / \text { day for } \\
44 \text { days }) \text { by oral administration }\end{array}$ & $\begin{array}{l}\text { Fructose-fed hypertensive male } \\
\text { Wistar rats }\end{array}$ & Tail-cuff plethysmography & No significant change in blood pressure \\
\hline
\end{tabular}




\section{Conclusions}

Isoflavones are phytoestrogen compounds with recognized beneficial effects in the cardiovascular system. Owing to minor structural differences, isoflavones modulate many cellular pathways that culminate in vasorelaxation, acting either in the endothelium, vascular smooth muscle, or both. Dietary intake or supplementation allow the attainment of sufficiently high plasma concentrations to produce significant vasodilation and lower blood pressure. Most studies have assessed the blood-pressure-lowering potential of these compounds in subjects consuming mixtures of isoflavones, with conflicting results, probably due to confounding variables. Only a few studies have focused on isolated compounds, where promising results were found, which should prompt future clinical studies. In order to better understand the cardiovascular potential of isoflavones, future studies should take into account not only the ingested dose of isoflavones but also the subjects' dietary habits and medical history, as well as the role of intestinal flora. This paper contributes to highlight isolated isoflavones as potentially suitable alternatives to soy-based foodstuffs and supplements, which could enlarge the current therapeutic arsenal.

Funding: This research received no external funding.

Institutional Review Board Statement: Not applicable.

Informed Consent Statement: Not applicable.

Data Availability Statement: No new data were created or analyzed in this study. Data sharing is not applicable to this article.

Conflicts of Interest: The author declares no conflict of interest.

\section{References}

1. Xu, X.; Duncan, A.M.; Merz, B.E.; Kurzer, M.S. Effects of soy isoflavones on estrogen and phytoestrogen metabolism in premenopausal women. Cancer Epidemiol. Biomarkers Prev. 1998, 7, 1101-1108.

2. Pino, A.M.; Valladares, L.E.; Palma, M.A.; Mancilla, A.M.; Yáñez, M.; Albala, C. Dietary isoflavones affect sex hormone-binding globulin levels in postmenopausal women. J. Clin. Endocrinol. Metab. 2000, 85, 2797-2800. [CrossRef] [PubMed]

3. Dakora, F.D.; Phillips, D.A. Diverse functions of isoflavonoids in legumes transcend anti-microbial definitions of phytoalexins. Physiol. Mol. Plant Pathol. 1996, 49, 1-20. [CrossRef]

4. Bellou, S.; Karali, E.; Bagli, E.; Al-Maharik, N.; Morbidelli, L.; Ziche, M.; Adlercreutz, H.; Murphy, C.; Fotsis, T. The isoflavone metabolite 6-methoxyequol inhibits angiogenesis and suppresses tumor growth. Mol. Cancer 2012, 11, 35. [CrossRef]

5. Křǐžová, L.; Dadáková, K.; Kašparovská, J.; Kašparovský, T. Isoflavones. Molecules 2019, 24, 1076. [CrossRef]

6. Ho, S.C.; Chen, Y.M.; Ho, S.S.S.; Woo, J.L.F. Soy isoflavone supplementation and fasting serum glucose and lipid profile among postmenopausal Chinese women: A double-blind, randomized, placebo-controlled trial. Menopause 2007, 14, 905-912. [CrossRef]

7. Wei, P.; Liu, M.; Chen, Y.; Chen, D.C. Systematic review of soy isoflavone supplements on osteoporosis in women. Asian Pac. J. Trop. Med. 2012, 5, 243-248. [CrossRef]

8. Rietjens, I.M.C.M.; Louisse, J.; Beekmann, K. The potential health effects of dietary phytoestrogens. Br. J. Pharmacol. 2017, 174, 1263-1280. [CrossRef]

9. Sarkar, F.H.; Li, Y. Soy Isoflavones and Cancer Prevention. Cancer Investig. 2003, 21, 744-757. [CrossRef]

10. Clarkson, T.B. Soy, Soy Phytoestrogens and Cardiovascular Disease. J. Nutr. 2002, 132, 566-569. [CrossRef]

11. Matthan, N.R.; Jalbert, S.M.; Ausman, L.M.; Kuvin, J.T.; Karas, R.H.; Lichtenstein, A.H. Effect of soy protein from differently processed products on cardiovascular disease risk factors and vascular endothelial function in hypercholesterolemic subjects. Am. J. Clin. Nutr. 2007, 85, 960-966. [CrossRef] [PubMed]

12. Teede, H.J.; McGrath, B.P.; DeSilva, L.; Cehun, M.; Fassoulakis, A.; Nestel, P.J. Isoflavones reduce arterial stiffness: A placebocontrolled study in men and postmenopausal women. Arterioscler. Thromb. Vasc. Biol. 2003, 23, 1066-1071. [CrossRef] [PubMed]

13. Nestel, P.J.; Pomeroy, S.; Sally, K.; Komesaroff, P.; Behrsing, J.; Cameron, J.D.; West, L. Isoflavones from red clover improve systemic arterial compliance but not plasma lipids in menopausal women. J. Clin. Endocrinol. Metab. 1999, 84, 895-898. [CrossRef]

14. Nestel, P.J.; Yamashita, T.; Sasahara, T.; Pomeroy, S.; Dart, A.; Komesaroff, P.; Owen, A.; Abbey, M. Soy isoflavones improve systemic arterial compliance but not plasma lipids in menopausal and perimenopausal women. Arterioscler. Thromb. Vasc. Biol. 1997, 17, 3392-3398. [CrossRef] [PubMed]

15. Dixon, R.A.; Sumner, L.W. Legume natural products: Understanding and manipulating complex pathways for human and animal health. Plant Physiol. 2003, 131, 878-885. [CrossRef]

16. Miller, K.A.; Frankel, F.; Takahashr, H.; Vance, N.; Stiegerwald, C.; Edelstein, S. Collected literature on isoflavones and chronic diseases. Cogent Food Agric. 2016, 2, 1135861. [CrossRef] 
17. Heinonen, S.M.; Wähälä, K.; Adlercreutz, H. Identification of urinary metabolites of the red clover isoflavones formononetin and biochanin A in human subjects. J. Agric. Food Chem. 2004, 52, 6802-6809. [CrossRef]

18. Lee, S.J.; Yan, W.; Ahn, J.K.; Chung, I.M. Effects of year, site, genotype and their interactions on various soybean isoflavones. Field Crop. Res. 2003, 81, 181-192. [CrossRef]

19. Cassidy, A.; Brown, J.E.; Hawdon, A.; Faughnan, M.S.; King, L.J.; Millward, J.; Zimmer-Nechemias, L.; Wolfe, B.; Setchelly, K.D.R. Factors affecting the bioavailability of soy isoflavones in humans after ingestion of physiologically relevant levels from different soy foods. J. Nutr. 2006, 136, 45-51. [CrossRef]

20. Franke, A.A.; Custer, L.J.; Wang, W.; Shi, C.Y. HPLC analysis of isoflavonoids and other phenolic agents from foods and from human fluids. Proc. Soc. Exp. Biol. Med. 1998, 217, 263-273. [CrossRef]

21. King, R.A.; Bursill, D.B. Plasma and urinary kinetics of the isoflavones daidzein and genistein after a single soy meal in humans. Am. J. Clin. Nutr. 1998, 67, 867-872. [CrossRef] [PubMed]

22. Watanabe, S.; Yamaguchi, M.; Sobue, T.; Takahashi, T.; Miura, T.; Arai, Y.; Mazur, W.; Wähälä, K.; Adlercreutz, H. Pharmacokinetics of soybean isoflavones in plasma, urine and feces of men after ingestion of $60 \mathrm{~g}$ baked soybean powder (kinako). J. Nutr. 1998, 128, 1710-1715. [CrossRef] [PubMed]

23. Xu, X.; Wang, H.J.; Murphy, P.A.; Cook, L.; Hendrich, S. Daidzein is a more bioavailable soymilk isoflavone than is genistein in adult women. J. Nutr. 1994, 124, 825-832. [CrossRef] [PubMed]

24. Chundi, V.; Challa, S.R.; Garikapati, D.R.; Juvva, G.; Jampani, A.; Pinnamaneni, S.H.; Venigalla, S. Biochanin-A attenuates neuropathic pain in diabetic rats. J. Ayurveda Integr. Med. 2016, 7, 231-237. [CrossRef] [PubMed]

25. Harini, R.; Ezhumalai, M.; Pugalendi, K.V. Antihyperglycemic effect of biochanin A, a soy isoflavone, on streptozotocin-diabetic rats. Eur. J. Pharmacol. 2012, 676, 89-94. [CrossRef] [PubMed]

26. Chukwumah, Y.C.; Walker, L.T.; Verghese, M.; Ogutu, S. Effect of frequency and duration of ultrasonication on the extraction efficiency of selected isoflavones and trans-resveratrol from peanuts (Arachis hypogaea). Ultrason. Sonochem. 2009, 16, 293-299. [CrossRef]

27. Zhang, L.; Li, Q.; Yang, X.; Xia, Z. Effects of sodium selenite and germination on the sprouting of chickpeas (Cicer arietinum L.) and its content of selenium, formononetin and biochanin A in the sprouts. Biol. Trace Elem. Res. 2012, 146, 376-380. [CrossRef] [PubMed]

28. Khedgikar, V.; Gautam, J.; Kushwaha, P.; Kumar, A.; Nagar, G.K.; Dixit, P.; Chillara, R.; Voruganti, S.; Singh, S.P.; Uddin, W.; et al. A standardized phytopreparation from an Indian medicinal plant (Dalbergia sissoo) has antiresorptive and bone-forming effects on a postmenopausal osteoporosis model of rat. Menopause 2012, 19, 1336-1346. [CrossRef]

29. Sartorelli, P.; Carvalho, C.S.; Reimão, J.Q.; Ferreira, M.J.P.; Tempone, A.G. Antiparasitic activity of biochanin A, an isolated isoflavone from fruits of Cassia fistula (Leguminosae). Parasitol. Res. 2009, 104, 311-314. [CrossRef]

30. Ming, X.; Ding, M.; Zhai, B.; Xiao, L.; Piao, T.; Liu, M. Biochanin A inhibits lipopolysaccharide-induced inflammation in human umbilical vein endothelial cells. Life Sci. 2015, 136, 36-41. [CrossRef]

31. Chen, J.; Ge, B.; Wang, Y.; Ye, Y.; Zeng, S.; Huang, Z. Biochanin a promotes proliferation that involves a feedback loop of microRNA-375 and estrogen receptor alpha in breast cancer cells. Cell. Physiol. Biochem. 2015, 35, 639-646. [CrossRef] [PubMed]

32. Howes, J.B.; Tran, D.; Brillante, D.; Howes, L.G. Effects of dietary supplementation with isoflavones from red clover on ambulatory blood pressure and endothelial function in postmenopausal type 2 diabetes. Diabetes Obes. Metab. 2003, 5, 325-332. [CrossRef] [PubMed]

33. Thorup, A.C.; Lambert, M.N.; Kahr, H.S.; Bjerre, M.; Jeppesen, P.B. Intake of novel red clover supplementation for 12 weeks improves bone status in healthy menopausal women. Evid.-Based Complement. Altern. Med. 2015, 2015. [CrossRef] [PubMed]

34. Lambert, M.N.T.; Thorup, A.C.; Hansen, E.S.S.; Jeppesen, P.B. Combined Red Clover isoflavones and probiotics potently reduce menopausal vasomotor symptoms. PLoS ONE 2017, 12, e0176590. [CrossRef]

35. Setchell, K.D.R.; Brown, N.M.; Lydeking-Olsen, E. The clinical importance of the metabolite equol-A clue to the effectiveness of soy and its isoflavones. J. Nutr. 2002, 132, 3577-3584. [CrossRef]

36. Szeja, W.; Grynkiewicz, G.; Rusin, A. Isoflavones, their Glycosides and Glycoconjugates. Synthesis and Biological Activity. Curr Org. Chem. 2016, 21, 218-235. [CrossRef]

37. Setchell, K.D.R.; Brown, N.M.; Desai, P.; Zimmer-Nechemias, L.; Wolfe, B.E.; Brashear, W.T.; Kirschner, A.S.; Cassidy, A.; Heubi, J.E. Bioavailability of pure isoflavones in healthy humans and analysis of commercial soy isoflavone supplements. J. Nutr. 2001, 131, 1362-1375. [CrossRef]

38. Figtree, G.A.; Griffiths, H.; Lu, Y.Q.; Webb, C.M.; MacLeod, K.; Collins, P. Plant-derived estrogens relax coronary arteries in vitro by a calcium antagonistic mechanism. J. Am. Coll. Cardiol. 2000, 35, 1977-1985. [CrossRef]

39. Varinska, L.; Gal, P.; Mojzisova, G.; Mirossay, L.; Mojzis, J. Soy and breast cancer: Focus on angiogenesis. Int. J. Mol. Sci. 2015, 16, 11728-11749. [CrossRef]

40. Lee, Y.J.; Cho, J.Y.; Kim, J.H.; Park, W.K.; Kim, D.K.; Rhyu, M.R. Extracts from Schizandra chinensis fruit activate estrogen receptors: A possible clue to its effects on nitric oxide-mediated vasorelaxation. Biol. Pharm. Bull. 2004, 27, 1066-1069. [CrossRef]

41. Dan Ramdath, D.; Padhi, E.M.T.; Sarfaraz, S.; Renwick, S.; Duncan, A.M. Beyond the cholesterol-lowering effect of soy protein: A review of the effects of dietary soy and its constituents on risk factors for cardiovascular disease. Nutrients 2017, 9, 324. [CrossRef] [PubMed] 
42. Tham, D.M.; Gardner, C.D.; Haskell, W.L. Potential health benefits of dietary phytoestrogens: A review of the clinical, epidemiological, and mechanistic evidence. J. Clin. Endocrinol. Metab. 1998, 83, 2223-2235. [CrossRef] [PubMed]

43. Bingham, S.A.; Atkinson, C.; Liggins, J.; Bluck, L.; Coward, A.; August, R.I.; Revised, I.; Accepted, I.D.; December, I. Phytooestrogens: Where are we now? Clin. Nutr. 1998, 44, 393-406. [CrossRef] [PubMed]

44. Adlercreutz, H.; Mousavi, Y.; Clark, J.; Höckerstedt, K.; Hämäläinen, E.; Wähälä, K.; Mäkelä, T.; Hase, T. Dietary phytoestrogens and cancer: In vitro and in vivo studies. J. Steroid Biochem. Mol. Biol. 1992, 41, 331-337. [CrossRef]

45. Merritt, J.C. Therapeutic options: Hormone replacement therapy-soy therapy. J. Natl. Med. Assoc. 2001, 93, $288-292$.

46. Hooper, L.; Kroon, P.A.; Rimm, E.B.; Cohn, J.S.; Harvey, I.; Cornu, K.A.L.; Ryder, J.J.; Hall, W.L.; Cassidy, A. Flavonoids, flavonoid-rich foods, and cardiovascular risk: A meta-analysis of randomized controlled trials 1, 2. Am. J. Clin. Nutr. 2008, 88, 38-50. [CrossRef]

47. Rosero Arenas, M.Á.; Rosero Arenas, E.; Portaceli Armiñana, M.A.; García García, M.Á. Utilidad de los fitoestrógenos en la reducción de la presión arterial. Revisión sistemática y metaanálisis. Aten. Primaria 2008, 40, 177-186. [CrossRef]

48. Taku, K.; Lin, N.; Cai, D.; Hu, J.; Zhao, X.; Zhang, Y.; Wang, P.; Melby, M.K.; Hooper, L.; Kurzer, M.S.; et al. Effects of soy isoflavone extract supplements on blood pressure in adult humans: Systematic review and meta-analysis of randomized placebo-controlled trials. J. Hypertens. 2010, 28, 1971-1982. [CrossRef]

49. Dong, J.Y.; Tong, X.; Wu, Z.W.; Xun, P.C.; He, K.; Qin, L.Q. Effect of soya protein on blood pressure: A meta-analysis of randomised controlled trials. Br. J. Nutr. 2011, 106, 317-326. [CrossRef]

50. Liu, X.X.; Li, S.H.; Chen, J.Z.; Sun, K.; Wang, X.J.; Wang, X.G.; Hui, R.T. Effect of soy isoflavones on blood pressure: A meta-analysis of randomized controlled trials. Nutr. Metab. Cardiovasc. Dis. 2012, 22, 463-470. [CrossRef]

51. Yan, Z.; Zhang, X.; Li, C.; Jiao, S.; Dong, W. Association between consumption of soy and risk of cardiovascular disease: A meta-analysis of observational studies. Eur. J. Prev. Cardiol. 2017, 24, 735-747. [CrossRef] [PubMed]

52. Namazi, N.; Saneei, P.; Larijani, B.; Esmaillzadeh, A. Soy product consumption and the risk of all-cause, cardiovascular and cancer mortality: A systematic review and meta-analysis of cohort studies. Food Funct. 2018, 9, 2576-2588. [CrossRef] [PubMed]

53. Nachvak, S.M.; Moradi, S.; Anjom-shoae, J.; Rahmani, J.; Nasiri, M.; Maleki, V.; Sadeghi, O. Soy, Soy Isoflavones, and Protein Intake in Relation to Mortality from All Causes, Cancers, and Cardiovascular Diseases: A Systematic Review and Dose-Response Meta-Analysis of Prospective Cohort Studies. J. Acad. Nutr. Diet. 2019, 119, 1483-1500.e17. [CrossRef] [PubMed]

54. Li, N.; Wu, X.; Zhuang, W.; Xia, L.; Chen, Y.; Zhao, R.; Yi, M.; Wan, Q.; Du, L.; Zhou, Y. Soy and Isoflavone Consumption and Multiple Health Outcomes: Umbrella Review of Systematic Reviews and Meta-Analyses of Observational Studies and Randomized Trials in Humans. Mol. Nutr. Food Res. 2020, 64, 1-12. [CrossRef]

55. Coward, L.; Smith, M.; Kirk, M.; Barnes, S. Chemical modification of isoflavones in soyfoods during cooking and processing. Am. J. Clin. Nutr. 1998, 68, 1486-1491. [CrossRef]

56. Slavin, J.L.; Karr, S.C.; Hutchins, A.M.; Lampe, J.W. Influence of soybean processing, habitual diet, and soy dose on urinary isoflavonoid excretion. Am. J. Clin. Nutr. 1998, 68, 1492-1495. [CrossRef]

57. Nakamura, Y.; Tsuji, S.; Tonogai, Y. Determination of the levels of isoflavonoids in soybeans and soy-derived foods and estimation of isoflavonoids in the Japanese daily intake. J. AOAC Int. 2000, 83, 635-650. [CrossRef]

58. Mayo, B.; Vázquez, L.; Flórez, A.B. Equol: A bacterial metabolite from the daidzein. Nutrients 2019, 11, 2231. [CrossRef]

59. Rossi, M.; Amaretti, A.; Roncaglia, L.; Leonardi, A.; Raimondi, S. Dietary isoflavones and intestinal microbiota: Metabolism and transformation into bioactive compounds. In Isoflavones: Biosynthesis, Occurrence and Health Effects; Thompson, M.J., Ed.; Nova Publisher: New York, NY, USA, 2010; pp. 137-161.

60. Day, A.J.; Cañada, F.J.; Díaz, J.C.; Kroon, P.A.; McLauchlan, R.; Faulds, C.B.; Plumb, G.W.; Morgan, M.R.A.; Williamson, G. Dietary flavonoid and isoflavone glycosides are hydrolysed by the lactase site of lactase phlorizin hydrolase. FEBS Lett. 2000, 468, 166-170. [CrossRef]

61. Yokoyama, S.I.; Suzuki, T. Isolation and characterization of a novel equol-producing bacterium from human feces. Biosci. Biotechnol. Biochem. 2008, 72, 2660-2666. [CrossRef]

62. Rothwell, J.A.; Day, A.J.; Morgan, M.R.A. Experimental determination of octanol-water partition coefficients of quercetin and related flavonoids. J. Agric. Food Chem. 2005, 53, 4355-4360. [CrossRef] [PubMed]

63. Wu, J.G.; Ge, J.; Zhang, Y.P.; Yu, Y.; Zhang, X.Y. Solubility of genistein in water, methanol, ethanol, propan-2-ol, 1-butanol, and ethyl acetate from (280 to 333) K. J. Chem. Eng. Data 2010, 55, 5286-5288. [CrossRef]

64. Kwon, S.H.; Kang, M.J.; Huh, J.S.; Ha, K.W.; Lee, J.R.; Lee, S.K.; Lee, B.S.; Han, I.H.; Lee, M.S.; Lee, M.W.; et al. Comparison of oral bioavailability of genistein and genistin in rats. Int. J. Pharm. 2007, 337, 148-154. [CrossRef] [PubMed]

65. Steensma, A.; Faassen-Peters, M.A.W.; Noteborn, H.P.J.M.; Rietjens, I.M.C.M. Bioavailability of genistein and its glycoside genistin as measured in the portal vein of freely moving unanesthetized rats. J. Agric. Food Chem. 2006, 54, 8006-8012. [CrossRef] [PubMed]

66. Chen, J.; Lin, H.; Hu, M. Metabolism of flavonoids via enteric recycling: Role of intestinal disposition. J. Pharmacol. Exp. Ther. 2003, 304, 1228-1235. [CrossRef] [PubMed]

67. Enokizono, J.; Kusuhara, H.; Sugiyama, Y. Effect of breast cancer resistance protein (Bcrp/Abcg2) on the disposition of phytoestrogens. Mol. Pharmacol. 2007, 72, 967-975. [CrossRef] 
68. Álvarez, A.I.; Vallejo, F.; Barrera, B.; Merino, G.; Prieto, J.G.; Tomás-Barberán, F.; Espín, J.C. Bioavailability of the Glucuronide and Sulfate Conjugates of Genistein and Daidzein in Breast Cancer Resistance Protein 1 Knockout Mice Received. Drug Metab. Dispos. 2012, 39, 2008-2012. [CrossRef]

69. Yang, Z.; Kulkarni, K.; Zhu, W.; Hu, M. Bioavailability and Pharmacokinetics of Genistein: Mechanistic Studies on its ADME. Anticancer Agents Med. Chem. 2012, 12, 1264-1280. [CrossRef]

70. Coldham, N.G.; Sauer, M.J. Pharmacokinetics of [14C]genistein in the rat: Gender-related differences, potential mechanisms of biological action, and implications for human health. Toxicol. Appl. Pharmacol. 2000, 164, 206-215. [CrossRef]

71. Heinonen, S.M.; Hoikkala, A.; Wähälä, K.; Adlercreutz, H. Metabolism of the soy isoflavones daidzein, genistein and glycitein in human subjects. Identification of new metabolites having an intact isoflavonoid skeleton. J. Steroid Biochem. Mol. Biol. 2003, 87, 285-299. [CrossRef]

72. Liu, Y.A.N.; Hu, M. Absorption and metabolism of flavonoids in the caco-2 cell culture model and a perused rat intestinal model. Drug Metab. Dispos. 2002, 30, 370-377. [CrossRef] [PubMed]

73. Coldham, N.G.; Darby, C.; Hows, M.; King, L.J.; Zhang, A.Q.; Sauer, M.J. Comparative metabolism of genistin by human and rat gut microflora: Detection and identification of the end-products of metabolism. Xenobiotica 2002, 32, 45-62. [CrossRef] [PubMed]

74. Hosoda, K.; Furuta, T.; Yokokawa, A.; Ogura, K.; Hiratsuka, A.; Ishii, K. Plasma profiling of intact isoflavone metabolites by high-performance liquid chromatography and mass spectrometric identification of flavone glycosides daidzin and genistin in human plasma after administration of kinako. Drug Metab. Dispos. 2008, 36, 1485-1495. [CrossRef] [PubMed]

75. Lu, L.J.W.; Anderson, K.E. Sex and long-term soy diets affect the metabolism and excretion of soy isoflavones in humans. Am. J. Clin. Nutr. 1998, 68, 1500-1504. [CrossRef] [PubMed]

76. Chen, G.; Zhang, J.; Ye, J. Determination of puerarin, daidzein and rutin in Pueraria lobata (Wild.) Ohwi by capillary electrophoresis with electrochemical detection. J. Chromatogr. A 2001, 923, 255-262. [CrossRef]

77. Murphy, P.A.; Song, T.; Buseman, G.; Barua, K.; Beecher, G.R.; Trainer, D.; Holden, J. Isoflavones in retail and institutional soy foods. J. Agric. Food Chem. 1999, 47, 2697-2704. [CrossRef]

78. Barnes, S.; Kirk, M.; Coward, L. Isoflavones and Their Conjugates in Soy Foods: Extraction Conditions and Analysis by HPLC-Mass Spectrometry. J. Agric. Food Chem. 1994, 42, 2466-2474. [CrossRef]

79. Totta, P.; Acconcia, F.; Virgili, F.; Cassidy, A.; Weinberg, P.D.; Rimbach, G.; Marino, M. Daidzein-sulfate metabolites affect transcriptional and antiproliferative activities of estrogen receptor- $\beta$ in cultured human cancer cells. J. Nutr. 2005, 135, 2687-2693. [CrossRef]

80. Rowland, I.R.; Wiseman, H.; Sanders, T.A.B.; Adlercreutz, H.; Bowey, E.A. Interindividual variation in metabolism of soy isoflavones and lignans: Influence of habitual diet on equol production by the gut microflora. Nutr. Cancer 2000, 36, 27-32. [CrossRef]

81. Soidinsalo, O.; Wähälä, K. Synthesis of phytoestrogenic isoflavonoid disulfates. Steroids 2004, 69, 613-616. [CrossRef]

82. Setchell, K.D.R.; Faughnan, M.S.; Avades, T.; Zimmer-Nechemias, L.; Brown, N.M.; Wolfe, B.E.; Brashear, W.T.; Desai, P.; Oldfield, M.F.; Botting, N.P.; et al. Comparing the pharmacokinetics of daidzein and genistein with the use of 13C-labeled tracers in premenopausal women. Am. J. Clin. Nutr. 2003, 77, 411-419. [CrossRef] [PubMed]

83. Fanti, P.; Sawaya, B.P.; Custer, L.J.; Franke, A.A. Serum levels and metabolic clearance of the isoflavones genistein and daidzein in hemodialysis patients. J. Am. Soc. Nephrol. 1999, 10, 864-871. [PubMed]

84. Qu, Y.; Zhang, Z.; Lu, Y.; Zheng, D.; Wei, Y. Network Pharmacology Reveals the Molecular Mechanism of Cuyuxunxi Prescription in Promoting Wound Healing in Patients with Anal Fistula. Evid. Based Complement. Altern. Med. 2019, 2019, 3865121. [CrossRef]

85. Luo, L.Y.; Fan, M.X.; Zhao, H.Y.; Li, M.X.; Wu, X.; Gao, W.Y. Pharmacokinetics and Bioavailability of the Isoflavones Formononetin and Ononin and Their in Vitro Absorption in Ussing Chamber and Caco-2 Cell Models. J. Agric. Food Chem. 2018, 66, 2917-2924. [CrossRef] [PubMed]

86. Singh, S.P.; Wahajuddin; Raju, K.S.R.; Ali, M.M.; Kohli, K.; Jain, G.K. Reduced bioavailability of tamoxifen and its metabolite 4-hydroxytamoxifen after oral administration with Biochanin A (an Isoflavone) in rats. Phyther. Res. 2012, 26, 303-307. [CrossRef] [PubMed]

87. Singh, S.P.; Wahajuddin; Tewari, D.; Pradhan, T.; Jain, G.K. PAMPA permeability, plasma protein binding, blood partition, pharmacokinetics and metabolism of formononetin, a methoxylated isoflavone. Food Chem. Toxicol. 2011, 49, 1056-1062. [CrossRef]

88. Han, H.K.; Lee, B.J.; Lee, H.K. Enhanced dissolution and bioavailability of biochanin A via the preparation of solid dispersion: In vitro and in vivo evaluation. Int. J. Pharm. 2011, 415, 89-94. [CrossRef]

89. Moon, Y.J.; Sagawa, K.; Frederick, K.; Zhang, S.; Morris, M.E. Pharmacokinetics and bioavailability of the isoflavone biochanin A in rats. AAPS J. 2006, 8, E433-E442.

90. Setchell, K.D.R.; Clerici, C.; Lephart, E.D.; Cole, S.J.; Heenan, C.; Castellani, D.; Wolfe, B.E.; Nechemias-Zimmer, L.; Brown, N.M.; Lund, T.D.; et al. S-equol, a potent ligand for estrogen receptor $\beta$, is the exclusive enantiomeric form of the soy isoflavone metabolite produced by human intestinal bacterial flora. Am. J. Clin. Nutr. 2005, 81, 1072-1079. [CrossRef]

91. Nagel, S.C.; Vom Saal, F.S.; Welshons, W.V. The Effective Free Fraction of Estradiol Measured by Whole Cell Uptake Assays: And Xenoestrogens in Human Serum Physiology of Delivery Modifies Estrogenic Activity. Exp. Biol. Med. 1998, 217, 300-309. [CrossRef] 
92. Bennetts, H.W.; Underwood, E.J.; Shier, F.L. A specific breeding problem of sheep on subterranean clover pastures in Western Australia. Br. Vet. J. 1946, 102, 348-352. [PubMed]

93. Millington, A.J.; Francis, C.M.; Mckeown, N.R. Wether bioassay of annual pasture legumes. II. The oestrogenic activity of nine strains of Trifolium subterraneum L. Aust. J. Agric. Res. 1964, 15, 527-536. [CrossRef]

94. Gil-Izquierdo, A.; Penalvo, J.L.; Gil, J.I.; Medina, S.; Horcajada, M.N.; Lafay, S.; Silberberg, M.; Llorach, R.; Zafrilla, P.; Garcia-Mora, P.; et al. Soy Isoflavones and Cardiovascular Disease Epidemiological, Clinical and -Omics Perspectives. Curr. Pharm. Biotechnol. 2012, 13, 624-631. [CrossRef] [PubMed]

95. Gardana, C.; Canzi, E.; Simonetti, P. The role of diet in the metabolism of daidzein by human faecal microbiota sampled from Italian volunteers. J. Nutr. Biochem. 2009, 20, 940-947. [CrossRef]

96. Nagata, C.; Ueno, T.; Uchiyama, S.; Nagao, Y.; Yamamoto, S.; Shibuya, C.; Kashiki, Y.; Shimizu, H. Dietary and lifestyle correlates of urinary excretion status of equol in Japanese women. Nutr. Cancer 2008, 60, 49-54. [CrossRef]

97. Tanaka, M.; Fujimoto, K.; Chihara, Y.; Torimoto, K.; Yoneda, T.; Tanaka, N.; Hirayama, A.; Miyanaga, N.; Akaza, H.; Hirao, Y. Isoflavone supplements stimulated the production of serum equol and decreased the serum dihydrotestosterone levels in healthy male volunteers. Prostate Cancer Prostatic Dis. 2009, 12, 247-252. [CrossRef]

98. Liu, Z.M.; Ho, S.C.; Chen, Y.M.; Tomlinson, B.; Ho, S.; To, K.; Woo, J. Effect of whole soy and purified daidzein on ambulatory blood pressure and endothelial function-a 6-month double-blind, randomized controlled trial among Chinese postmenopausal women with prehypertension. Eur. J. Clin. Nutr. 2015, 69, 1161-1168. [CrossRef]

99. Jackman, K.A.; Woodman, O.L.; Chrissobolis, S.; Sobey, C.G. Vasorelaxant and antioxidant activity of the isoflavone metabolite equol in carotid and cerebral arteries. Brain Res. 2007, 1141, 99-107. [CrossRef]

100. Kelly, G.E.; Joannou, G.E.; Reeder, A.Y.; Nelson, C.; Waring, M.A. The Variable Metabolic Response to Dietary Isoflavones in Humans. Proc. Soc. Exp. Biol. Med. 1995, 208, 40-43. [CrossRef]

101. Jefferson, W.N.; Patisaul, H.B.; Williams, C.J. Reproductive Consequences of Developmental Phytoestrogen Exposure. Reproduction 2012, 143, 247-260. [CrossRef]

102. Piotrowska, K.; Baranowska-Bosiacka, I.; Marchlewicz, M.; Gutowska, I.; Noceń, I.; Zawiślak, M.; Chlubek, D.; Wiszniewska, B. Changes in male reproductive system and mineral metabolism induced by soy isoflavones administered to rats from prenatal life until sexual maturity. Nutrition 2011, 27, 372-379. [CrossRef] [PubMed]

103. Talsness, C.; Grote, K.; Kuriyama, S.; Presibella, K.; Sterner-Kock, A.; Poça, K.; Chahoud, I. Prenatal Exposure to the Phytoestrogen Daidzein Resulted in Persistent Changes in Ovarian Surface Epithelial Cell Height, Folliculogenesis, and Estrus Phase Length in Adult Sprague-Dawley Rat Offspring. J. Toxicol. Environ. Health Part A Curr. Issues 2015, 78, 635-644. [CrossRef] [PubMed]

104. Greathouse, K.L.; Bredfeldt, T.; Everitt, J.I.; Lin, K.; Berry, T.; Kannan, K.; Mittelstadt, M.L.; Ho, S.M.; Walker, C.L. Environmental estrogens differentially engage the histone methyltransferase EZH2 to increase risk of uterine tumorigenesis. Mol. Cancer Res. 2012, 10, 546-557. [CrossRef] [PubMed]

105. van Doorn-Khosrovani, S.B.v.W.; Janssen, J.; Maas, L.M.; Godschalk, R.W.L.; Nijhuis, J.G.; van Schooten, F.J. Dietary flavonoids induce MLL translocations in primary human CD34+ cells. Carcinogenesis 2007, 28, 1703-1709. [CrossRef]

106. Balakrishnan, B.; Thorstensen, E.B.; Ponnampalam, A.P.; Mitchell, M.D. Transplacental Transfer and Biotransformation of Genistein in Human Placenta. Placenta 2010, 31, 506-511. [CrossRef]

107. Setchell, K.D.R.; Zimmer-Nechemias, L.; Cai, J.; Heubi, J.E. Exposure of infants to phyto-oestrogens from soy-based infant formula. Lancet 1997, 350, 23-27. [CrossRef]

108. Franke, A.A.; Custer, L.J. Daidzein and genistein concentrations in human milk after soy consumption. Clin. Chem. 1996, 42, 955-964. [CrossRef]

109. Franke, A.A.; Lai, J.F.; Halm, B.M. Absorption, distribution, metabolism, and excretion of isoflavonoids after soy intake. Arch Biochem. Biophys. 2014, 559, 24-28. [CrossRef]

110. Woo, J.; Lynn, H.; Lau, W.Y.; Leung, J.; Lau, E.; Wong, S.Y.S.; Kwok, T. Nutrient intake and psychological health in an elderly Chinese population. Int. J. Geriatr. Psychiatry 2006, 21, 1036-1043. [CrossRef]

111. Hogervorst, E.; Sadjimim, T.; Yesufu, A.; Kreager, P.; Rahardjo, T.B. High tofu intake is associated with worse memory in elderly Indonesian men and women. Dement. Geriatr. Cogn. Disord. 2008, 26, 50-57. [CrossRef]

112. White, L.R.; White, L.R.; Petrovitch, H.; White, L.R.; Petrovitch, H.; Ross, G.W.; Masaki, K.; Hardman, J.; White, L.R.; Ross, G.W.; et al. Brain Aging and Midlife Tofu Consumption. J. Am. Coll. Nutr. 2000, 19, 242-255. [CrossRef] [PubMed]

113. Coates, P.; Betz, J.M.; Blackman, M.R.; Cragg, G.; Levine, M.; Moss, J.; White, J. Encyclopedia of Dietary Supplements Encyclopedia of Dietary Supplements; Taylor \& Francis Group LLC: Boca Raton, FL, USA; CRC Press: Boca Raton, FL, USA, 2010; ISBN 9781439819289.

114. Chang, H.C.; Doerge, D.R. Dietary genistein inactivates rat thyroid peroxidase in vivo without an apparent hypothyroid effect. Toxicol. Appl. Pharmacol. 2000, 168, 244-252. [CrossRef] [PubMed]

115. Radović, B.; Mentrup, B.; Köhrle, J. Genistein and other soya isoflavones are potent ligands for transthyretin in serum and cerebrospinal fluid. Br. J. Nutr. 2006, 95, 1171-1176. [CrossRef] [PubMed]

116. Chorazy, P.A.; Himelhoch, S.; Hopwood, N.J.; Greger, N.G.; Postellon, D.C. Persistent hypothyroidism in an infant receiving a soy formula: Case report and review of the literature. Pediatrics 1995, 96, 148-149. [PubMed]

117. Dillingham, B.L.; McVeigh, B.L.; Lampe, J.W.; Duncan, A.M. Soy Protein Isolates of Varied Isoflavone Content Do Not Influence Serum Thyroid Hormones in Healthy Young Men. Thyroid 2007, 17, 131-137. [CrossRef] [PubMed] 
118. Messina, M.; Redmond, G. Effects of soy protein and soybean isoflavones on thyroid function in healthy adults and hypothyroid patients: A review of the relevant literature. Thyroid 2006, 16, 249-258. [CrossRef]

119. Li, Y.; Kong, D.; Bao, B.; Ahmad, A.; Sarkar, F.H. Induction of cancer cell death by isoflavone: The role of multiple signaling pathways. Nutrients 2011, 3, 877-896. [CrossRef]

120. Van Die, M.D.; Bone, K.M.; Williams, S.G.; Pirotta, M.V. Soy and soy isoflavones in prostate cancer: A systematic review and meta-analysis of randomized controlled trials. BJU Int. 2014, 113, 119-130. [CrossRef]

121. Yu, Y.; Jing, X.; Li, H.; Zhao, X.; Wang, D. Soy isoflavone consumption and colorectal cancer risk: A systematic review and meta-analysis. Sci. Rep. 2016, 6, 25939. [CrossRef]

122. Sun, C.L.; Yuan, J.M.; Wang, X.L.; Gao, Y.T.; Ross, R.K.; Yu, M.C. Dietary soy and increased risk of bladder cancer: A prospective cohort study of men in Shanghai, China. Int. J. Cancer 2004, 112, 319-323. [CrossRef]

123. Sun, C.L.; Yuan, J.M.; Arakawa, K.; Low, S.H.; Lee, H.P.; Yu, M.C. Dietary soy and increased risk of bladder cancer: The Singapore Chinese Health Study. Cancer Epidemiol. Biomark. Prev. 2002, 11, 1674-1677.

124. Rossi, M.; Strikoudi, P.; Spei, M.E.; Parpinel, M.; Serraino, D.; Montella, M.; Libra, M.; La Vecchia, C.; Rosato, V. Flavonoids and bladder cancer risk. Cancer Causes Control 2019, 30, 527-535. [CrossRef] [PubMed]

125. Messing, E.; Gee, J.R.; Saltzstein, D.R.; Kim, K.M.; DiSant'Agnese, A.; Kolesar, J.; Harris, L.; Faerber, A.; Havighurst, T.; Young, J.M.; et al. A phase 2 cancer chemoprevention biomarker trial of isoflavone G-2535 (genistein) in presurgical bladder cancer patients. Cancer Prev. Res. 2012, 5, 621-630. [CrossRef] [PubMed]

126. Messina, M.J.; Wood, C.E. Soy isoflavones, estrogen therapy, and breast cancer risk: Analysis and commentary. Nutr. J. 2008, 7, $1-12$.

127. Shu, X.O.; Zheng, Y.; Cai, H.; Gu, K.; Chen, Z.; Zheng, W.; Lu, W. Soy food intake and breast cancer survival. JAMA J. Am. Med. Assoc. 2009, 302, 2437-2443. [CrossRef] [PubMed]

128. Shin, H.R.; Joubert, C.; Boniol, M.; Hery, C.; Ahn, S.H.; Won, Y.J.; Nishino, Y.; Sobue, T.; Chen, C.J.; You, S.L.; et al. Recent trends and patterns in breast cancer incidence among Eastern and Southeastern Asian women. Cancer Causes Control 2010, 21, 1777-1785. [CrossRef]

129. van Erp-Baart, M.-A.J.; Brants, H.A.M.; Kiely, M.; Mulligan, A.; Turrini, A.; Sermoneta, C.; Kilkkinen, A.; Valsta, L.M. Isoflavone intake in four different European countries: The VENUS approach. Br. J. Nutr. 2003, 89, S25-S30. [CrossRef]

130. Messina, M.; Nagata, C.; Wu, A.H. Estimated Asian adult soy protein and isoflavone intakes. Nutr. Cancer 2006, 55, 1-12. [CrossRef]

131. Messina, M.; Hilakivi-Clarke, L. Early intake appears to be the key to the proposed protective effects of soy intake against breast cancer. Nutr. Cancer 2009, 61, 792-798. [CrossRef]

132. Nishio, K.; Niwa, Y.; Toyoshima, H.; Tamakoshi, K.; Kondo, T.; Yatsuya, H.; Yamamoto, A.; Suzuki, S.; Tokudome, S.; Lin, Y.; et al. Consumption of soy foods and the risk of breast cancer: Findings from the Japan Collaborative Cohort (JACC) Study. Cancer Causes Control 2007, 18, 801-808. [CrossRef]

133. McMichael-Phillips, D.F.; Harding, C.; Morton, M.; Roberts, S.A.; Howell, A.; Potten, C.S.; Bundred, N.J. Effects of soy-protein supplementation on epithelial proliferation in the histologically normal human breast. Am. J. Clin. Nutr. 1998, 68, 1431S-1435S. [CrossRef] [PubMed]

134. Horn-Ross, P.L.; John, E.M.; Canchola, A.J.; Stewart, S.L.; Lee, M.M. Phytoestrogen intake and endometrial cancer risk. J. Natl. Cancer Inst. 2003, 95, 1158-1164. [CrossRef] [PubMed]

135. Xu, W.H.; Zheng, W.; Xiang, Y.B.; Ruan, Z.X.; Cheng, J.R.; Dai, Q.; Gao, Y.T.; Shu, X.O. Soya food intake and risk of endometrial cancer among Chinese women in Shanghai: Population based case-control study. Br. Med. J. 2004, 328, 1285-1288. [CrossRef] [PubMed]

136. Murray, M.J.; Meyer, W.R.; Lessey, B.A.; Oi, R.H.; DeWire, R.E.; Fritz, M.A. Soy protein isolate with isoflavones does not prevent estradiol-induced endometrial hyperplasia in postmenopausal women: A pilot trial. Menopause 2003, 10, 456-464. [CrossRef] [PubMed]

137. Lightfoot, R.J.; Croker, K.P.; Neil, H.G. Failure of sperm transport in relation to ewe infertility following prolonged grazing on oestrogenic pastures. Aust. J. Agric. Res. 1967, 18, 740-753. [CrossRef]

138. Mustonen, E.; Taponen, S.; Andersson, M.; Sukura, A.; Katila, T.; Taponen, J. Fertility and growth of nulliparous ewes after feeding red clover silage with high phyto-oestrogen concentrations. Animal 2014, 8, 1699-1705. [CrossRef]

139. Sandoo, A.; Veldhuijzen van Zanten, J.J.C.; Metsios, G.S.; Carroll, D.; Kitas, G.D. The Endothelium and Its Role in Regulating Vascular Tone. Open Cardiovasc. Med. J. 2015, 4, 302-312. [CrossRef]

140. Aalkjær, C.; Boedtkjer, D.; Matchkov, V. Vasomotion-What is currently thought? Acta Physiol. 2011, 202, 253-269. [CrossRef]

141. Wong, B.J. Sensory nerves and nitric oxide contribute to reflex cutaneous vasodilation in humans. Am. J. Physiol. Regul. Integr. Comp. Physiol. 2013, 304, 651-656. [CrossRef]

142. Ghosh, D.; Syed, A.U.; Prada, M.P.; Nystoriak, M.A.; Santana, L.F.; Nieves-Cintrón, M.; Navedo, M.F. Calcium Channels in Vascular Smooth Muscle. Adv. Pharmacol. 2017, 78, 49-87.

143. Fernández-Tenorio, M.; Porras-González, C.; Castellano, A.; Del Valle-Rodríguez, A.; López-Barneo, J.; Ureña, J. Metabotropic Regulation of RhoA/Rho-Associated Kinase by New Mechanism for Depolarization-Evoked Mammalian Arterial Contraction SR. Circ. Res. 2011, 108, 1348-1357. [CrossRef] [PubMed]

144. Förstermann, U.; Sessa, W.C. Nitric oxide synthases: Regulation and function. Eur. Heart J. 2012, 33, 1-13. [CrossRef] 
145. Chambliss, K.L.; Shaul, P.W. Estrogen modulation of endothelial nitric oxide synthase. Endocr. Rev. 2002, 23, 665-686. [CrossRef]

146. Campbell, W.B.; Gauthier, K.M. Role of the 15-Lipoxygenase-EDHF Pathway. J. Cardiovasc. Pharmacol. 2014, 61, 176-187. [CrossRef] [PubMed]

147. Watts, S.W.; Yeum, C.H.; Webb, C.; Campbell, G. Serotonin Stimulates Protein Tyrosyl Phosphorylation and Vascular Contraction via Tyrosine Kinase. J. Vasc. Res. 1996, 33, 288-298. [CrossRef] [PubMed]

148. Nevala, R.; Korpela, R.; Vapaatalo, H. Plant Derived Estrogens Relax Rat Mesenteric Artery In Vitro. Life Sci. 1998, 63, PL95-PL100. [CrossRef]

149. Mishra, S.K.; Abbot, S.E.; Choudhury, Z.; Cheng, M.; Khatab, N.; Maycock, N.J.R.; Zavery, A.; Aaronson, P.I. Endotheliumdependent relaxation of rat aorta and main pulmonary artery by the phytoestrogens genistein and daidzein. Cardiovasc. Res. 2000, 46, 539-546. [CrossRef]

150. Ajay, M.; Gilani, A.U.H.; Mustafa, M.R. Effects of flavonoids on vascular smooth muscle of the isolated rat thoracic aorta. Life Sci. 2003, 74, 603-612. [CrossRef]

151. Galán-Martínez, L.; Herrera-Estrada, I.; Fleites-Vázquez, A. Direct actions of the flavonoids naringenin, quercetin and genistein on rat cardiac and vascular muscles. J. Pharm. Pharmacogn. Res. 2018, 6, 158-166.

152. Je, H.D.; Sohn, U.D. Inhibitory effect of genistein on agonist-induced modulation of vascular contractility. Mol. Cells 2009, 27, 191-198. [CrossRef]

153. Filipeanu, C.M.; Brailoiu, E.; Huhurez, G.; Slatineanu, S.; Baltatu, O.; Branisteanu, D.D. Multiple effects of tyrosine kinase inhibitors on vascular smooth muscle contraction. Eur. J. Pharmacol. 1995, 281, 29-35. [CrossRef]

154. Sun, T.; Liu, R.; Cao, Y.X. Vasorelaxant and antihypertensive effects of formononetin through endothelium-dependent and -independent mechanisms. Acta Pharmacol. Sin. 2011, 32, 1009-1018. [CrossRef] [PubMed]

155. Torregrosa, G.; Burguete, M.C.; Pérez-Asensio, F.J.; Salom, J.B.; Gil, J.V.; Alborch, E. Pharmacological profile of phytoestrogens in cerebral vessels: In vitro study with rabbit basilar artery. Eur. J. Pharmacol. 2003, 482, 227-234. [CrossRef] [PubMed]

156. Squadrito, F.; Altavilla, D.; Squadrito, G.; Saitta, A.; Cucinotta, D.; Minutoli, L.; Deodato, B.; Ferlito, M.; Campo, G.M.; Bova, A.; et al. Genistein supplementation and estrogen replacement therapy improve endothelial dysfunction induced by ovariectomy in rats. Cardiovasc. Res. 2000, 45, 454-462. [CrossRef]

157. Pinna, C.; Sala, A. Sex-specific activity of hesperidin, diosmin and genistein on human umbilical vein. Biomed. Res. Clin. Pract. 2019, 4, 1-5. [CrossRef]

158. Roghani, M.; Vaez Mahdavi, M.R.; Jalali-Nadoushan, M.R.; Baluchnejadmojarad, T.; Naderi, G.; Roghani-Dehkordi, F.; Taghi Joghataei, M.; Kord, M. Chronic administration of daidzein, a soybean isoflavone, improves endothelial dysfunction and attenuates oxidative stress in streptozotocin- induced diabetic rats. Phyther. Res. 2013, 27, 112-117. [CrossRef]

159. Prawez, S.; Ahanger, A.A.; Singh, T.U.; Mishra, S.K.; Sarkar, S.N.; Rahman, S. Chronic administration of phytoestrogen "daidzein" to ameliorate mean arterial pressure and vascular function in N-G-nitro-L-arginine methyl ester hypertensive rats. Vet. Arh. 2015, $85,451-464$.

160. Woodman, O.L.; Missen, M.A.; Boujaoude, M. Daidzein and $17 \beta$-estradiol enhance nitric oxide synthase activity associated with an increase in calmodulin and a decrease in caveolin-1. J. Cardiovasc. Pharmacol. 2004, 44, 155-163. [CrossRef]

161. Sobey, C.G.; Weiler, J.M.; Boujaoude, M.; Woodman, O.L. Effect of short-term phytoestrogen treatment in male rats on nitric oxide-mediated responses of carotid and cerebral arteries: Comparison with 17 $\beta$-estradiol. J. Pharmacol. Exp. Ther. 2004, 310, 135-140. [CrossRef]

162. Sharma, S.; Singh, M.; Sharma, P.L. Ameliorative effect of daidzein: A caveolin-1 inhibitor in vascular endothelium dysfunction induced by ovariectomy. Indian J. Exp. Biol. 2012, 50, 28-34.

163. Chen, Z.; Oliveira, S.D.S.; Zimnicka, A.M.; Jiang, Y.; Sharma, T.; Chen, S.; Lazarov, O.; Bonini, M.G.; Haus, J.M.; Minshall, R.D. Reciprocal regulation of eNOS and caveolin-1 functions in endothelial cells. Mol. Biol. Cell 2018, 29, 1190-1202. [CrossRef] [PubMed]

164. GOVERS, R.; RABELINK, T.J. Cellular regulation of endothelial nitric oxide synthase. Am. J. Physiol. Ren. Physiol. 2001, 280, F193-F206. [CrossRef] [PubMed]

165. Hishikawa, K.; Nakaki, T.; Marumo, T.; Suzuki, H.; Kato, R.; Saruta, T. Up-regulation of nitric oxide synthase by estradiol in human aorticendothelial cells. FEBS Lett. 1995, 360, 291-293.

166. Michel, J.B.; Feron, O.; Sacks, D.; Michel, T. Reciprocal regulation of endothelial nitric-oxide synthase by $\mathrm{Ca}^{2+}$-calmodulin and caveolin. J. Biol. Chem. 1997, 272, 15583-15586. [CrossRef] [PubMed]

167. Wu, J.H.; Li, Q.; Wu, M.Y.; Guo, D.J.; Chen, H.L.; Chen, S.L.; Seto, S.W.; Au, A.L.S.; Poon, C.C.W.; Leung, G.P.H.; et al. Formononetin, an isoflavone, relaxes rat isolated aorta through endothelium-dependent and endothelium-independent pathways. J. Nutr. Biochem. 2010, 21, 613-620. [CrossRef] [PubMed]

168. Tseng, H.H.L.; Vong, C.T.; Leung, G.P.H.; Seto, S.W.; Kwan, Y.W.; Lee, S.M.Y.; Hoi, M.P.M. Calycosin and Formononetin Induce Endothelium-Dependent Vasodilation by the Activation of Large-Conductance $\mathrm{Ca}^{2+}$-Activated $\mathrm{K}^{+} \mathrm{Channels}$ (BKCa). Evid. Based Complement. Altern. Med. 2016, 2016, 5272531. [CrossRef]

169. Li, T.; Zhong, Y.; Tang, T.; Luo, J.; Cui, H.; Fan, R.; Wang, Y.; Wang, D. Formononetin induces vasorelaxation in rat thoracic aorta via regulation of the PI3K/PTEN/Akt signaling pathway. Drug Des. Devel. Ther. 2018, 12, 3675-3684. [CrossRef]

170. Sun, T.; Cao, L.; Ping, N.N.; Wu, Y.; Liu, D.Z.; Cao, Y.X. Formononetin upregulates nitric oxide synthase in arterial endothelium through estrogen receptors and MAPK pathways. J. Pharm. Pharmacol. 2016, 68, 342-351. [CrossRef] 
171. Zheng, J.; Bird, I.M.; Melsaether, A.N.; Magness, R.R. Activation of the mitogen-activated protein kinase cascade is necessary but not sufficient for basic fibroblast growth factor- and epidermal growth factor-stimulated expression of endothelial nitric oxide synthase in ovine fetoplacental artery endothelial. Endocrinology 1999, 140, 1399-1407. [CrossRef]

172. Mata-Greenwood, E.; Liao, W.-X.; Zheng, J.; Chen, D.-B. Differential Activation of Multiple Signaling Pathways Dictates eNOS Upregulation by FGF2 but not VEGF in Placental Artery Endothelial Cells. Placenta 2008, 29, 708-717. [CrossRef]

173. Xing, F.; Jiang, Y.; Liu, J.; Zhao, K.; Mo, Y.; Liu, Z.; Zeng, Y. Downregulation of human endothelial nitric oxide synthase promoter activity by $\mathrm{p} 38$ mitogen-activated protein kinase activation. Biochem. Cell Biol. 2006, 84, 780-788. [CrossRef] [PubMed]

174. Siow, R.C.M.; Li, F.Y.L.; Rowlands, D.J.; de Winter, P.; Mann, G.E. Cardiovascular targets for estrogens and phytoestrogens: Transcriptional regulation of nitric oxide synthase and antioxidant defense genes. Free Radic. Biol. Med. 2007, 42, 909-925. [CrossRef] [PubMed]

175. Wang, H.P.; Gao, Q.; Mei, R.H.; Zhao, M.H.; Lu, Y.; Li, X.Y.; Bruce, I.C.; Xia, Q. Mechanisms underlying biochanin A-induced relaxation of the aorta differ between normotensive and hypertensive rats. Clin. Exp. Pharmacol. Physiol. 2006, 33, 802-807. [CrossRef] [PubMed]

176. Choi, S.; Jung, W.S.; Cho, N.S.; Ryu, K.H.; Jun, J.Y.; Shin, B.C.; Chung, J.H.; Yeum, C.H. Mechanisms of phytoestrogen biochanin A-induced vasorelaxation in renovascular hypertensive rats. Kidney Res. Clin. Pract. 2014, 33, 181-186. [CrossRef]

177. Migkos, T.; Pourová, J.; Vopršalová, M.; Auger, C.; Schini-Kerth, V.; Mladěnka, P. Biochanin A, the Most Potent of 16 Isoflavones, Induces Relaxation of the Coronary Artery through the Calcium Channel and cGMP-dependent Pathway. Planta Med. 2020, 86, 708-716. [CrossRef]

178. Chin-Dusting, J.P.F.; Fisher, L.J.; Lewis, T.V.; Piekarska, A.; Nestel, P.J.; Husband, A. The vascular activity of some isoflavone metabolites: Implications for a cardioprotective role. Br. J. Pharmacol. 2001, 133, 595-605. [CrossRef]

179. Joy, S.; Siow, R.C.M.; Rowlands, D.J.; Becker, M.; Wyatt, A.W.; Aaronson, P.I.; Coen, C.W.; Kallo, I.; Jacob, R.; Mann, G.E. The isoflavone equol mediates rapid vascular relaxation: $\mathrm{Ca}^{2+}$-independent activation of endothelial nitric-oxide synthase/Hsp90 involving ERK1/2 and Akt phosphorylation in human endothelial cells. J. Biol. Chem. 2006, 281, 27335-27345. [CrossRef]

180. Ohkura, Y.; Obayashi, S.; Yamada, K.; Yamada, M.; Kubota, T. S-equol partially restored endothelial nitric oxide production in isoflavone-deficient ovariectomized rats. J. Cardiovasc. Pharmacol. 2015, 65, 500-507. [CrossRef]

181. Kim, J.Y.; Lee, M.Y.; Park, H.M. The Effect of Eqoul, a Metabolite of Isoflavone, on Endothelial Cell-independent Vasodilatation of Human Uterine Artery In Vitro. J. Bone Metab. 2015, 22, 57. [CrossRef]

182. Cheng, C.; Wang, X.; Weakley, S.M.; Kougias, P.; Lin, P.H.; Yao, Q.; Chen, C. The soybean isoflavonoid equol blocks ritonavirinduced endothelial dysfunction in porcine pulmonary arteries and human pulmonary artery endothelial cells. J. Nutr. 2010, 140, 12-17. [CrossRef]

183. Ng, W.W.; Keung, W.; Xu, Y.C.; Ng, K.F.; Leung, G.P.; Vanhoutte, P.M.; Choy, P.C.; Man, R.Y. Genistein potentiates protein kinase A activity in porcine coronary artery. Mol. Cell. Biochem. 2008, 311, 37-44. [CrossRef] [PubMed]

184. Zhao, Y.; Chen, B.N.; Wang, S.B.; Wang, S.H.; Du, G.H. Vasorelaxant effect of formononetin in the rat thoracic aorta and its mechanisms. J. Asian Nat. Prod. Res. 2012, 14, 46-54. [CrossRef] [PubMed]

185. Wang, H.P.; Mei, R.H.; Li, X.Y.; Zhao, M.H.; Lu, Y.; Bruce, I.C.; Xia, Q. Endothelium-independent vasorelaxant effect of the phyto-oestrogen biochanin A on rat thoracic aorta. In Proceedings of the 2005 IEEE Engineering in Medicine and Biology 27th Annual Conference, Shanghai, China, 17-18 January 2006; Volume 3, pp. 2244-2247.

186. Gimenez, I.; Lou, M.; Vargas, F.; Alvarez-Guerra, M.; Mayoral, J.A.; Martinez, R.M.; Garay, R.P.; Alda, J.O. Renal and vascular actions of equol in the rat. J. Hypertens. 1997, 15, 1303-1308. [CrossRef] [PubMed]

187. Smirnov, S.V.; Aaronson, P.I. Inhibition of vascular smooth muscle cell $\mathrm{K}^{+}$currents by tyrosine kinase inhibitors genistein and ST 638. Circ. Res. 1995, 76, 310-316. [CrossRef]

188. Woodman, O.L.; Boujaoude, M. Chronic treatment of male rats with daidzein and $17 \beta$-oestradiol induces the contribution of EDHF to endothelium-dependent relaxation. Br. J. Pharmacol. 2004, 141, 322-328. [CrossRef]

189. Zhang, H.T.; Wang, Y.; Deng, X.L.; Dong, M.Q.; Zhao, L.M.; Wang, Y.W. Daidzein relaxes rat cerebral basilar artery via activation of large-conductance $\mathrm{Ca}^{2+}$-activated $\mathrm{K}^{+}$channels in vascular smooth muscle cells. Eur. J. Pharmacol. 2010, 630, 100-106. [CrossRef]

190. Nevala, R.; Paukku, K.; Korpela, R.; Vapaatalo, H. Calcium-sensitive potassium channel inhibitors antagonize genistein- and daidzein-induced arterial relaxation in vitro. Life Sci. 2001, 69, 1407-1417. [CrossRef]

191. Chan, H.Y.; Yao, X.; Tsang, S.Y.; Chan, F.L.; Lau, C.W.; Huang, Y. Different role of endothelium/nitric oxide in 17 $\beta$-estradiol- and progesterone-induced relaxation in rat arteries. Life Sci. 2001, 69, 1609-1617. [CrossRef]

192. Kang, K.T. Endothelium-derived relaxing factors of small resistance arteries in hypertension. Toxicol. Res. 2014, 30, 141-148. [CrossRef]

193. Garland, C.J.; Dora, K.A. EDH: Endothelium-dependent hyperpolarization and microvascular signalling. Acta Physiol. 2017, 219, 152-161. [CrossRef] [PubMed]

194. Matsumoto, T.; Takayanagi, K.; Kobayashi, S.; Kojima, M.; Taguchi, K.; Kobayashi, T. Effect of equol on vasocontractions in rat carotid arteries treated with high insulin. Biol. Pharm. Bull. 2019, 42, 1048-1053. [CrossRef] [PubMed]

195. Yu, W.; Wang, Y.; Song, Z.; Zhao, L.M.; Li, G.R.; Deng, X.L. Equol increases cerebral blood flow in rats via activation of largeconductance $\mathrm{Ca}^{2+}$-activated $\mathrm{K}^{+}$channels in vascular smooth muscle cells. Pharmacol. Res. 2016, 107, 186-194. [CrossRef] [PubMed] 
196. Khanna, A.; Cowled, P.A.; Fitridge, R.A. Nitric oxide and skeletal muscle reperfusion injury: Current controversies (research review). J. Surg. Res. 2005, 128, 98-107. [CrossRef] [PubMed]

197. Valero, M.S.; Garay, R.P.; Gros, P.; Alda, J.O. Cystic fibrosis transmembrane conductance regulator (CFTR) chloride channel and $\mathrm{Na}-\mathrm{K}-\mathrm{Cl}$ cotransporter NKCC1 isoform mediate the vasorelaxant action of genistein in isolated rat aorta. Eur. J. Pharmacol. 2006, 544, 126-131. [CrossRef]

198. Satake, N.; Shibata, S. The potentiating effect of genistein on the relaxation induced by isoproterenol in rat aortic rings. Gen. Pharmacol. 1999, 33, 221-227. [CrossRef]

199. Abebe, W.; Agrawal, D.K. Role of tyrosine kinases in norepinephrine-induced contraction of vascular smooth muscle. J. Cardiovasc. Pharmacol. 1995, 26, 153-159. [CrossRef]

200. Inoue, R.; Waniishi, Y.; Yamada, K.; Ito, Y. A possible role of tyrosine kinases in the regulation of muscarinic receptor-activated cation channels in guinea pig ileum. Biochem. Biophys. Res. Commun. 1994, 203, 1392-1397. [CrossRef]

201. Liu, H.; Li, K.; Sperelakis, N. Tyrosine kinase inhibitor, genistein, inhibits macroscopic L-type calcium current in rat portal vein smooth muscle cells. Can. J. Physiol. Pharmacol. 1997, 75, 1058-1062. [CrossRef]

202. Kitazono, T.; Ibayashi, S.; Nagao, T.; Kagiyama, T.; Kitayama, J.; Fujishima, M. Role of tyrosine kinase in serotonin-induced constriction of the basilar artery in vivo. Stroke 1998, 29, 494-498. [CrossRef]

203. Akiyama, T.; Ishida, J.; Nakagawa, S.; Ogawara, H.; Watanabe, S.; Itoh, N.; Shibuya, M.; Fukami, Y. Genistein, a specific inhibitor of tyrosine-specific protein kinases. J. Biol. Chem. 1987, 262, 5592-5595. [CrossRef]

204. Zerrouk, A.; Auguet, M.; Dabiré, H.; Brisac, A.M.; Safar, M.; Chabrier, P.E. Differential effects of tyrosine kinase inhibitors on contraction and relaxation of the aortas of normotensive and hypertensive rats. Eur. J. Pharmacol. 1999, 374, 49-58. [CrossRef]

205. Nevala, R.; Lassila, M.; Finckenberg, P.; Paukku, K.; Korpela, R.; Vapaatalo, H. Genistein treatment reduces arterial contractions by inhibiting tyrosine kinases in ovariectomized hypertensive rats. Eur. J. Pharmacol. 2002, 452, 87-96. [CrossRef]

206. Lee, M.Y.K.; Man, R.Y.K. The phytoestrogen genistein enhances endothelium-independent relaxation in the porcine coronary artery. Eur. J. Pharmacol. 2003, 481, 227-232. [CrossRef]

207. Kimoto, Y.; Kinoshita, H.; Nakahata, K.; Dojo, M.; Hatano, Y. Inhibitory effects of lidocaine and mexiletine on vasorelaxation mediated by adenosine triphosphate-sensitive $\mathrm{K}+$ channels and the role of kinases in the porcine coronary artery. Anesthesiology 2005, 102, 581-587. [CrossRef]

208. Zhou, R.; Liu, L.; Hu, D. Involvement of BKCa $\alpha$ subunit tyrosine phosphorylation in vascular hyporesponsiveness of superior mesenteric artery following hemorrhagic shock in rats. Cardiovasc. Res. 2005, 68, 327-335. [CrossRef]

209. Duarte, J.; Ocete, M.A.; Pérez-Vizcaino, F.; Zarzuelo, A.; Tamargo, J. Effect of tyrosine kinase and tyrosine phosphatase inhibitors on aortic contraction and induction of nitric oxide synthase. Eur. J. Pharmacol. 1997, 338, 25-33. [CrossRef]

210. Bermejo, A.; Zarzuelo, A.; Duarte, J. In vivo vascular effects of genistein on a rat model of septic shock induced by lipopolysaccharide. J. Cardiovasc. Pharmacol. 2003, 42, 329-338. [CrossRef]

211. Moritoki, H.; Hisayama, T.; Takeuchi, S.; Kondoh, W.; Takeji, Y. Possible involvement of tyrosine kinase in the LPS-promoted initiation of L-arginine-induced relaxation of rat aorta mediated by induction of NO synthase. Life Sci. 1995, 57, 2-7. [CrossRef]

212. Yin, G.; Yan, C.; Berk, B.C. Angiotensin II signaling pathways mediated by tyrosine kinases. Int. J. Biochem. Cell Biol. 2003, 35, 780-783. [CrossRef]

213. Xu, Y.Y.; Yang, C.; Li, S.N. Effects of genistein on angiotensin-converting enzyme in rats. Life Sci. 2006, 79, 828-837. [CrossRef] [PubMed]

214. Liu, C.; Tazzeo, T.; Lippton, H.; Janssen, L.J. Role of tyrosine phosphorylation in U46619-induced vasoconstriction of pulmonary vasculature and its modulation by genistein, daidzein, and equol. J. Cardiovasc. Pharmacol. 2007, 50, 441-448. [CrossRef] [PubMed]

215. Zhang, M.; Wu, Y.; Wang, M.; Wang, Y.; Tausif, R.; Yang, Y. Genistein rescues hypoxia-induced pulmonary arterial hypertension through estrogen receptor and $\beta$-adrenoceptor signaling. J. Nutr. Biochem. 2018, 58, 110-118. [CrossRef] [PubMed]

216. Matori, H.; Umar, S.; Nadadur, R.D.; Sharma, S.; Partow-Navid, R.; Afkhami, M.; Amjedi, M.; Eghbali, M. Genistein, a Soy Phytoestrogen, Reverses Severe Pulmonary Hypertension and Prevents Right Heart Failure in Rats Humann. Hypertension 2012, 60, 425-430. [CrossRef]

217. Suenaga, H.; Kamata, K. Lysophosphatidylcholine potentiates vascular contractile responses in rat aorta via activation of tyrosine kinase. Br. J. Pharmacol. 2002, 135, 789-799. [CrossRef]

218. Kitayama, J.; Kitazono, T.; Ooboshi, H.; Ago, T.; Ohgami, T.; Fujishima, M.; Ibayashi, S. Chronic administration of a tyrosine kinase inhibitor restores functional and morphological changes of the basilar artery during chronic hypertension. J. Hypertens. 2002, 20, 2205-2211. [CrossRef]

219. Kuiper, G.G.J.M.; Lemmen, J.G.; Carlsson, B.; Corton, J.C.; Safe, S.H.; Van Der Saag, P.T.; Van Der Burg, B.; Gustafsson, J.Å. Interaction of estrogenic chemicals and phytoestrogens with estrogen receptor $\beta$. Endocrinology 1998, 139, 4252-4263. [CrossRef]

220. Escande, A.; Pillon, A.; Servant, N.; Cravedi, J.P.; Larrea, F.; Muhn, P.; Nicolas, J.C.; Cavaillès, V.; Balaguer, P. Evaluation of ligand selectivity using reporter cell lines stably expressing estrogen receptor alpha or beta. Biochem. Pharmacol. 2006, 71, 1459-1469. [CrossRef]

221. Song, T.T.; Hendrich, S.; Murphy, P.A. Estrogenic activity of glycitein, a soy isoflavone. J. Agric. Food Chem. 1999, 47, 1607-1610. [CrossRef]

222. Michael, E.; Mendelsohn, R.H.K. The protective effects of estrogen on the cardiovascular system. N. Engl. J. Med. 1999, 340, 1801-1811. 
223. Razandi, M.; Pedram, A.; Park, S.T.; Levin, E.R. Proximal events in signaling by plasma membrane estrogen receptors. J. Biol. Chem. 2003, 278, 2701-2712. [CrossRef] [PubMed]

224. Lin, A.H.Y.; Leung, G.P.H.; Leung, S.W.S.; Vanhoutte, P.M.; Man, R.Y.K. Genistein enhances relaxation of the spontaneously hypertensive rat aorta by transactivation of epidermal growth factor receptor following binding to membrane estrogen receptors$\alpha$ and activation of a $G$ protein-coupled, endothelial nitric oxide synthase-dependent pathway. Pharmacol. Res. 2011, 63, 181-189. [PubMed]

225. Sun, T.; Wang, J.; Huang, L.H.; Cao, Y.X. Antihypertensive effect of formononetin through regulating the expressions of eNOS, 5-HT2A/1B receptors and $\alpha 1$-adrenoceptors in spontaneously rat arteries. Eur. J. Pharmacol. 2013, 699, 241-249. [CrossRef] [PubMed]

226. Banie, L.; Lin, G.; Ning, H.; Wang, G.; Lue, T.F.; Lin, C.S. Effects of Estrogen, Raloxifene and Levormeloxifene on $\alpha 1 \mathrm{~A}-$ Adrenergic Receptor Expression. J. Urol. 2008, 180, 2241-2246. [CrossRef] [PubMed]

227. Mu, H.; Bai, Y.H.; Wang, S.T.; Zhu, Z.M.; Zhang, Y.W. Research on antioxidant effects and estrogenic effect of formononetin from Trifolium pratense (red clover). Phytomedicine 2009, 16, 314-319. [CrossRef] [PubMed]

228. Laniyonu, A.; Saifeddine, M.; Ahmad, S.; Hollenberg, M.D. Regulation of vascular and gastric smooth muscle contractility by pervanadate. Br. J. Pharmacol. 1994, 113, 403-410. [CrossRef]

229. Herrera, M.D.; Zarzuelo, A.; Jiménez, J.; Marhuenda, E.; Duarte, J. Effects of flavonoids on rat aortic smooth muscle contractility: Structure-activity relationships. Gen. Pharmacol. 1996, 27, 273-277. [CrossRef]

230. Vera, R.; Jiménez, R.; Lodi, F.; Sánchez, M.; Galisteo, M.; Zarzuelo, A.; Pérez-Vizcaíno, F.; Duarte, J. Genistein restores caveolin-1 and AT-1 receptor expression and vascular function in large vessels of ovariectomized hypertensive rats. Menopause 2007, 14, 933-940. [CrossRef]

231. Baluchnejadmojarad, T.; Roghani, M. Chronic administration of genistein improves aortic reactivity of streptozotocin-diabetic rats: Mode of action. Vasc. Pharmacol. 2008, 49, 1-5. [CrossRef]

232. Honoré, E.K.; Williams, J.K.; Anthony, M.S.; Clarkson, T.B. Soy isoflavones enhance coronary vascular reactivity in atherosclerotic female macaques. Fertil. Steril. 1997, 67, 148-154.

233. Cho, T.M.; Peng, N.; Clark, J.T.; Novak, L.; Roysommuti, S.; Prasain, J.; Wyss, J.M. Genistein attenuates the hypertensive effects of dietary $\mathrm{NaCl}$ in hypertensive male rats. Endocrinology 2007, 148, 5396-5402. [CrossRef] [PubMed]

234. Walker, H.A.; Dean, T.S.; Sanders, T.A.B.; Jackson, G.; Ritter, J.M.; Chowienczyk, P.J. The phytoestrogen genistein produces acute nitric oxide-dependent dilation of human forearm vasculature with similar potency to 17ßestradiol. Circulation 2001, 103, 258-262. [CrossRef] [PubMed]

235. Squadrito, F.; Altavilla, D.; Morabito, N.; Crisafulli, A.; D’Anna, R.; Corrado, F.; Ruggeri, P.; Campo, G.M.; Calapai, G.; Caputi, A.P.; et al. The effect of the phytoestrogen genistein on plasma nitric oxide concentrations, endothelin-1 levels and endothelium dependent vasodilation in postmenopausal women. Atherosclerosis 2002, 163, 339-347. [CrossRef]

236. Squadrito, F.; Altavilla, D.; Crisafulli, A.; Saitta, A.; Cucinotta, D.; Morabito, N.; Anna, R.D.; Corrado, F.; Ruggeri, P.; Frisina, N.; et al. Effect of Genistein on Endothelial Function in Double-Blind, Controlled Study. Am. J. Med. 2003, 114, 470-476. [CrossRef]

237. Cao, Y.X.; Yang, X.J.; Liu, J.; Li, K.X. Effects of daidzein sulfates on blood pressure and artery of rats. Basic Clin. Pharmacol. Toxicol. 2006, 99, 425-430. [CrossRef]

238. Sachdeva, C.; Mishra, N.; Sharma, S. Development and characterization of enteric-coated microparticles of biochanin A for their beneficial pharmacological potential in estrogen deficient-hypertension. Drug Deliv. 2016, 23, 2044-2057. [CrossRef]

239. Liu, T.H.; Tsai, T.Y. Effects of equol on deoxycorticosterone acetate salt-induced hypertension and associated vascular dementia in rats. Food Funct. 2016, 7, 3444-3457. [CrossRef]

240. Chin-Dusting, J.P.F.; Boak, L.; Husband, A.; Nestel, P.J. The isoflavone metabolite dehydroequol produces vasodilatation in human resistance arteries via a nitric oxide-dependent mechanism. Atherosclerosis 2004, 176, 45-48. [CrossRef]

241. Nestel, P.; Fujii, A.; Zhang, L. An isoflavone metabolite reduces arterial stiffness and blood pressure in overweight men and postmenopausal women. Atherosclerosis 2007, 192, 184-189. [CrossRef]

242. Morton, M.S.; Wilcox, G.; Wahlqvist, M.L.; Griffiths, K. Determination of lignans and isoflavonoids in human female plasma following dietary supplementation. J. Endocrinol. 1994, 142, 251-259. [CrossRef]

243. Drawz, P.; Ghazi, L. Advances in understanding the renin-angiotensin-aldosterone system (RAAS) in blood pressure control and recent pivotal trials of RAAS blockade in heart failure and diabetic nephropathy. F1000Research 2017, 6, 1-10.

244. Montenegro, M.F.; Pessa, L.R.; Tanus-santos, J.E. Isoflavone genistein inhibits the angiotensin-converting enzyme and alters the vascular responses to angiotensin I and bradykinin. Eur. J. Pharmacol. 2009, 607, 173-177. [CrossRef] [PubMed]

245. Xu, J.-W.; Ikeda, K.; Yamori, Y. Genistein Inhibits Expressions of NADPH Oxidase p22phox and Angiotensin II Type 1 Receptor in Aortic Endothelial Cells from Stroke-Prone Spontaneously Hypertensive Rats. Hypertens. Res. 2004, 27, 675-683. [CrossRef] [PubMed]

246. Pesce, N.; Eyster, K.M.; Williams, J.L.; Wixon, R.; Wang, C.; Martin, D.S. Effect of Genistein on Cardiovascular Responses to Angiotensin II in Conscious Unrestrained Rats. J. Cardiovasc. Pharmacol. 2000, 36, 806-809. [CrossRef] [PubMed]

247. Choudhury, A.; Pai, K.V. Angiotensin Converting Enzyme Inhibition Activity of Daidzein. Sci. Fed. Dent. Oral Res. J. 2017, 1, 92-98. [CrossRef]

248. Ma, H.J.; Liu, Y.X.; Wang, F.W.; Wang, L.X.; He, R.R.; Wu, Y.M. Genistein inhibits carotid sinus baroreceptor activity in anesthetized male rats. Acta Pharmacol. Sin. 2005, 26, 840-844. [CrossRef] 
249. Man, H.Y.; Erclik, T.; Becker, L.E.; Wang, Y.T. Modulation of baroreflex sensitivity by the state of protein tyrosine phosphorylation in the brainstem of the rat. Brain Res. 1998, 792, 141-148. [CrossRef]

250. Toyohira, Y.; Ueno, S.; Tsutsui, M.; Itoh, H.; Sakai, N.; Saito, N.; Takahashi, K.; Yanagihara, N. Stimulatory effects of the soy phytoestrogen genistein on noradrenaline transporter and serotonin transporter activity. Mol. Nutr. Food Res. 2010, 54, 516-524. [CrossRef]

251. Yanagihara, N.; Toyohira, Y.; Liu, M.; Ueno, S.; Tsutsui, M.; Zhang, H. Insights into the Pharmacological Effects of Soy Isoflavones on Catecholamine System. Soybean Health 2011. [CrossRef]

252. Masilamani, M.; Wei, J.; Sampson, H.A. Regulation of the immune response by soybean isoflavones. Immunol. Res. 2012, 54, 95-110. [CrossRef]

253. Palanisamy, N.; Venkataraman, A.C. Beneficial effect of genistein on lowering blood pressure and kidney toxicity in fructose-fed hypertensive rats. Br. J. Nutr. 2013, 109, 1806-1812. [CrossRef] [PubMed] 